\title{
Effects of a short-term experimental microclimate warming on the abundance and distribution of branched GDGTs in a French peatland
}

\author{
Arnaud Huguet ${ }^{\mathrm{a}, \mathrm{b}, *}$, Céline Fosse ${ }^{\mathrm{c}}$, Fatima Laggoun-Défarge ${ }^{\mathrm{d}, \mathrm{e}, \mathrm{f}}$, \\ Frédéric Delarue $^{\mathrm{d}, \mathrm{e}, \mathrm{f}}$, Sylvie Derenne ${ }^{\mathrm{a}, \mathrm{b}}$ \\ ${ }^{a}$ Université Pierre et Marie Curie, BioEMCo UMR 7618, 4 place Jussieu, Paris F-75252, France \\ ${ }^{\mathrm{b}}$ CNRS, BioEMCo UMR 7618, 4 place Jussieu, Paris F-75252, France \\ ${ }^{\mathrm{c}}$ Chimie ParisTech (ENSCP), Laboratoire de Spectrométrie de Masse, 11 rue Pierre et Marie Curie, Paris F-75231, France \\ ${ }^{\mathrm{d}}$ Université d'Orléans, ISTO, UMR 7327, Orléans F-45071, France \\ ${ }^{\mathrm{e}}$ CNRS/INSU, ISTO, UMR 7327, Orléans F-45071, France \\ ${ }^{\mathrm{f}}$ BRGM, ISTO, UMR 7327, BP 36009, Orléans F-45060, France
}

Received 24 January 2012; accepted in revised form 28 November 2012; Available online 19 December 2012

\begin{abstract}
Branched glycerol dialkyl glycerol tetraethers (GDGTs) are complex lipids of high molecular weight, recently discovered in soils and increasingly used as palaeoclimate proxies. Their degree of methylation, expressed in the MBT, was shown to depend on mean annual air temperature (MAAT) and to a lesser extent on soil $\mathrm{pH}$, whereas the relative abundance of cyclopentyl rings of branched GDGTs, expressed in the CBT, was related to soil pH. To date, only a few studies were interested in the application of the MBT and CBT proxies in peatlands. In order to validate the applicability of branched GDGTs as temperature proxies in these environments, it is essential to investigate the effect of temperature on branched GDGT-producing bacteria and especially on the speed of adaptation of these microorganisms to temperature changes. The aim of this work was to study the effects of in situ experimental climate warming on the abundance and distribution of branched GDGTs in a Sphagnum-dominated peatland (Jura Mountains, France). Branched GDGTs either present as core lipids (CLs; presumed of fossil origin) or derived from intact polar lipids (IPLs, markers for living cells) were analysed. Air temperature was experimentally increased using a passive warming system consisting of open mini-greenhouses (open-top chamber - OTC). The effect of the OTCs was especially apparent in spring and summer, with (i) an increase in maximal air temperature of ca. $3{ }^{\circ} \mathrm{C}$ during these two seasons and (ii) an increase in average air temperature of ca. $1{ }^{\circ} \mathrm{C}$ in summer. Despite the short duration of the climate experiment ( 26 months), branched GDGT distribution was significantly affected by this temperature rise, with higher MBT values in the OTCs than in the control plots, supporting the empirical relationship between MBT and MAAT established from a large range of soils. The difference in branched GDGT-derived temperatures between control and OTC plots $\left(2-3{ }^{\circ} \mathrm{C}\right)$ was in the same range as the increase in maximal (daytime) temperature induced by the OTCs in spring and summer, suggesting that branched GDGT-producing bacteria might be more active during the warmest months of the year. The OTC treatment had no significant effect on the abundance of branched GDGTs, which were mainly present as "fossil" CLs (70-85\% of the total branched GDGT pool). Furthermore, no significant differences in branched GDGT distribution were observed between the CLs and IPLs, which both provided higher MBT and MAAT values for the OTCs. This suggests that the fossil pool of branched GDGTs has a very fast turnover (less than the 2 year duration of the experiment) at the peat
\end{abstract}

\footnotetext{
* Corresponding author at: Université Pierre et Marie Curie, BioEMCo UMR 7618, 4 place Jussieu, Paris F-75252, France. Tel.: +33 144 275 172; fax: +33 144275150 .

E-mail address: arnaud.huguet@upmc.fr (A. Huguet).
} 
surface and that branched GDGT distribution may rapidly reflect changes in environmental conditions (at least air temperature) occurring in peat environments.

(c) 2012 Elsevier Ltd. All rights reserved.

\section{INTRODUCTION}

Glycerol dialkyl glycerol tetraethers (GDGTs) are complex lipids of high molecular weight $(M>1000 \mathrm{Da})$, present in membranes of Archaea and some bacteria. Archaeal membranes are formed predominantly by isoprenoid GDGTs with acyclic or ring-containing biphytanyl chains, while bacteria generally synthesise membrane lipids composed of straight or branched alkyl chains linked by ester bonds to the glycerol backbone. Nevertheless, another group of GDGT lipids, containing branched instead of isoprenoid alkyl chains was discovered in peat deposits (Fig. 1; Sinninghe Damsté et al., 2000). Based on aspects of their structures and stereochemistry, branched GDGTs were suggested to be produced by as yet unknown bacteria in soils (Weijers et al., 2006). These might belong to the phylum Acidobacteria (Weijers et al., 2009; Sinninghe Damsté et al., 2011). Branched GDGTs occur ubiquitously in soils (Weijers et al., 2007a, 2011a; Huguet et al., 2010a; Kim et al., 2011) and peats (Liu et al., 2010; Huguet et al., 2010b; Weijers et al., 2011b) as well as in lakes (Tierney and Russell, 2009; Bechtel et al., 2010; Tierney et al., 2010; Zink et al., 2010; Pearson et al., 2011) and coastal marine sediments (Hopmans et al., 2004; Kim et al., 2007). These compounds are the object of a growing interest. Indeed, branched GDGT distribution in soil was shown to depend primarily on air temperature and soil $\mathrm{pH}$

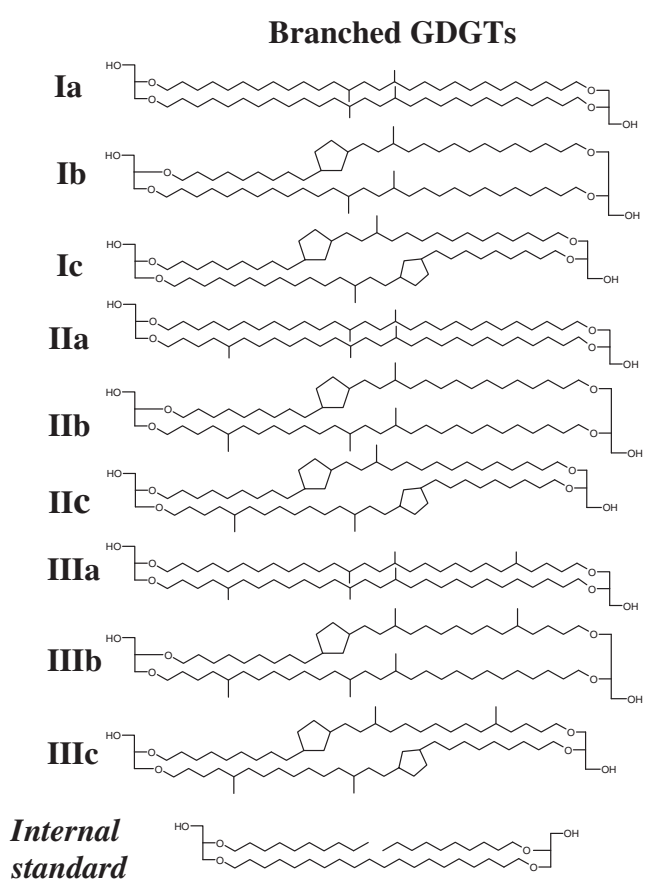

$m / z$

1018

\section{standard}

Fig. 1. Stuctures of branched glycerol dialkyl glycerol tetraether (GDGT) membrane lipids and of internal standard (IS).
(Weijers et al., 2007a). The degree of cyclisation of the membrane lipids, expressed in the cyclisation ratio of branched tetraethers (CBT), correlates rather well with soil $\mathrm{pH}$ and the degree of methylation, expressed in the methylation index of branched tetraethers (MBT) depends on mean annual air temperature (MAAT) and to a lesser extent on soil $\mathrm{pH}$. The MBT and CBT indices are increasingly used as palaeoenvironmental proxies and have been successfully applied to the reconstruction of past air temperatures in deltaic and coastal regions (e.g. the Congo fan, Weijers et al., 2007b; the North Sea, Donders et al., 2009; Rueda et al., 2009) and very recently in Chinese loess (Peterse et al., 2011a) based on comparison with instrumental records and/or data obtained from other proxies.

Despite promising results, some uncertainty exists about the calibration of the MBT/CBT. Indeed, these proxies have been empirically established and the direct effect of temperature and $\mathrm{pH}$ on the relative distribution of branched tetraether membrane lipids has only been rarely evaluated. Very recently, $\mathrm{pH}$ was shown to have a direct influence on branched GDGT distribution through the analysis of long-term soil $\mathrm{pH}$ manipulation plots (Peterse et al., 2010). In addition, a strong temperature dependence of the branched GDGT distribution was observed in geothermally heated soils (Peterse et al., 2009a) and in altitudinal (1700-3300 m) transects on Mt. Kilimanjaro, Tanzania and Mt. Gongga, China (Sinninghe Damsté et al., 2008; Peterse et al., 2009b). Nevertheless, other environmental factors than temperature and $\mathrm{pH}$, such as soil humidity, may also have an effect on the distribution of branched GDGTs in peat (Huguet et al., 2010b) and soils (Loomis et al., 2011). This could explain the remaining scatter in the CBT-pH and MBT-pH-MAAT relationships established by Weijers et al. (2007a) and part of the uncertainty in the MBT/CBT-reconstructed temperatures. An additional bias may come from the MBT/CBT-calibration set (Weijers et al., 2007a), which only contains surface mineral soil samples and does not include some specific organic soils such as peatlands.

To date, only a few studies were interested in the application of the MBT and CBT proxies in peatlands (Ballantyne et al., 2010; Huguet et al., 2010b; Weijers et al., 2011b). Nevertheless, the environmental and ecological significance of peat soils is immense. Even though their total cover only extends to $3-5 \%$ of the world's land area, northern peatlands contain $20-30 \%$ of the world's soil C stock (Gorham, 1991). In addition to the high organic carbon preservation, ombrotrophic mires are of great interest for climate studies since they are hydrologically independent of groundwater (Laiho, 2006) and consequently their substrate moisture levels are directly related to atmospheric conditions. Before reliably using branched GDGTs as temperature proxies in peatlands, their applicability in such specific environments has to be validated. For this, it seems 
essential to study the effect of temperature on branched GDGT-producing bacteria and especially to determine the speed of adaptation of these microorganisms to temperature changes. In this study, we investigated the impact of a 2 year experimental climate warming on the abundance and the distribution of branched GDGTs in a Sphagnum-dominated peatland located in the Jura Mountains (Frasne, France). Temperature was artificially increased in half of the sampling plots using open mini-greenhouses, and was compared with control plots. In all plots, branched GDGTs present as core and intact polar lipids were analysed. Intact polar lipids (IPLs) contain a polar head group and are presumably derived from recently active microorganisms, whereas core lipids (CLs), which are hydrolysates of IPLs, are presumed to be of fossil origin.

\section{MATERIALS AND METHODS}

\subsection{Site and sampling}

Samples were collected from the Frasne peatland $\left(46^{\circ} 49^{\prime} \mathrm{N}, 6^{\circ} 10^{\prime} \mathrm{E}\right)$, an undisturbed Sphagnum-dominated mire located in the Jura Mountains (France) at an altitude of $840 \mathrm{~m}$ above sea level (Fig. 2). The site, protected by the EU Habitat Directive of Natura 2000, has been classified as a Region Natural Reserve for more than 20 years. The climate of the region is characterized by cold winters (on average $-1.4{ }^{\circ} \mathrm{C}$ ) and mild summers (on average $14.6^{\circ} \mathrm{C}$ ). Annual precipitation is about $1300-1500 \mathrm{~mm}$ per year and mean annual air temperature measured at the site over the 2010 year was $6.2^{\circ} \mathrm{C}$.

Samples were collected from two adjacent and contrasting sites (Fig. 3): (i) a transitional Sphagnum-dominated poor fen area and (ii) an open bog area with mixed vegetation (Sphagnum spp., Eriophorum and other vascular plants, e.g. Andromeda polifolia), where the water table level is lower than at the first site. The latter site is hereafter called the "bog site" and the former the "fen site". The terms "fen" and "bog" are used here for simplicity and denote the existence of a trophic and wetness gradient inferred from the vegetation (Delarue et al., 2011). In 2009 and 2010, the average water table level was at $16.5 \mathrm{~cm}$ depth at the bog site and at $14 \mathrm{~cm}$ depth at the fen site.

The experimental design was described in detail in previous studies (Delarue et al., 2011; Jassey et al., 2011). Briefly, in each of the two sampling sites, six randomised plots have been chosen. Among the 12 sampling plots (Fig. 3), the maximal distance between the two most distant plots was ca. $30 \mathrm{~m}$. In both sampling sites, 3 plots (replicates) were randomly assigned as controls and 3 plots were assigned as climate warming treatment (begin April 2008). An increase in air temperature was passively achieved using a warming system consisting of open mini-greenhouses (open-top chamber - OTC) placed at $10 \mathrm{~cm}$ over Sphagnum capitulum (Marion et al., 1997). The OTCs (Fig. 4) are made of transparent hexagonal polycarbonate chambers (50 $\mathrm{cm}$ high and $1.6-1.8 \mathrm{~m}$ in diameter at the top and 2.2 $2.5 \mathrm{~m}$ at the base). They have particularly been used to study phenological changes of specific plant species to climate change in arctic and subarctic areas (Aerts et al., 2004). In each plot, air (10 cm above the Sphagnum capitulum) and soil ( $7 \mathrm{~cm}$ below the Sphagnum capitulum) temperatures are recorded continuously every $30 \mathrm{~min}$ using thermocouple probes (error on recorded temperatures: ca. $0.2{ }^{\circ} \mathrm{C}$ ) and a datalogger (CR-1000 Campbell). Due to technical problems, air temperature was continuously recorded from November 2008 to December 2010 only.

In order to compare the abundance and distribution of branched GDGTs in the control and OTC plots at the beginning of the climate warming treatment, 8 peat cores

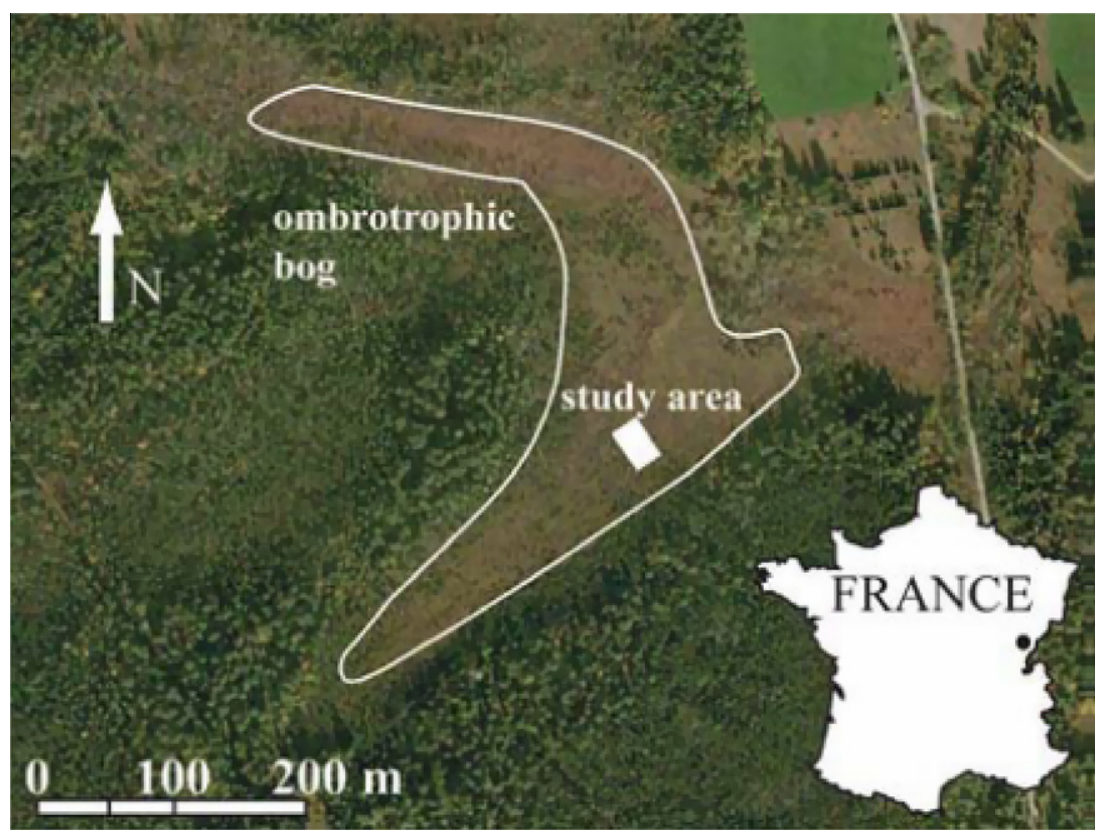

Fig. 2. Map showing the location of the site of study: Frasne peatland (Jura Mountains, France). 


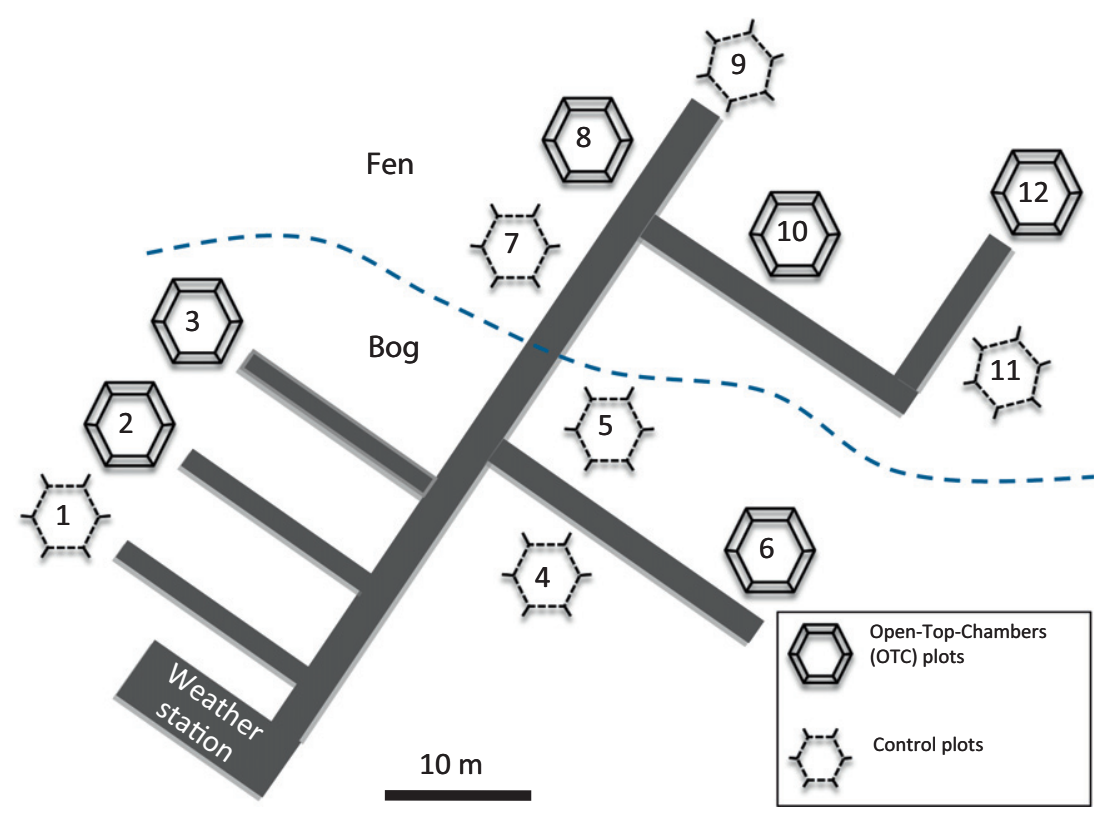

Fig. 3. Experimental design. In Frasne peatland, two sites were selected as a function of moisture conditions: an open bog ("bog site") and a transitional poor fen ("fen site"). At each site, six randomised plots have been chosen: three were equipped with open-top chambers (OTC) and three were taken as controls.

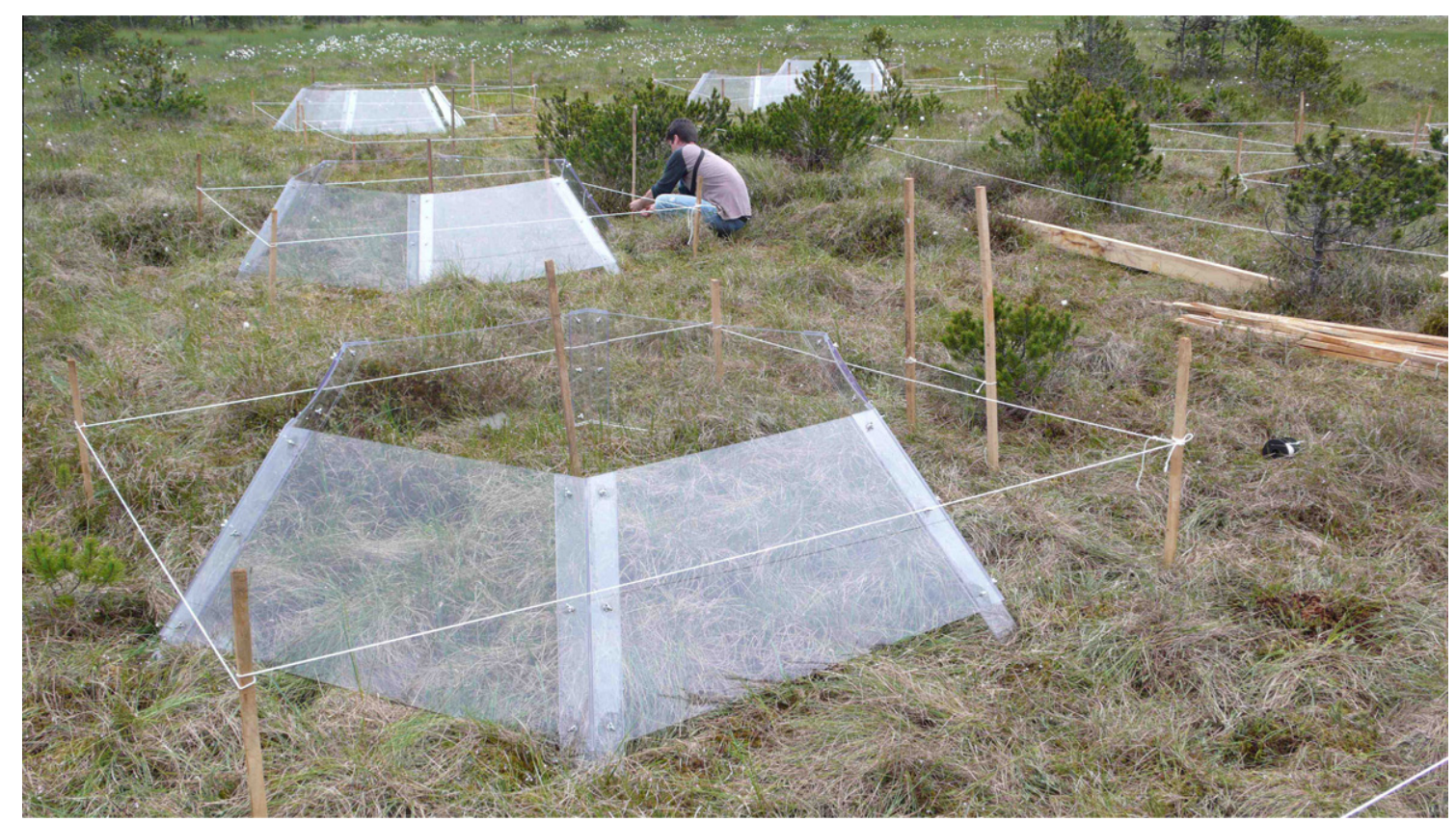

Fig. 4. Photograph of an open-top chamber (OTC) used for climate warming treatment in the Frasne peatland.

(25 cm long) were collected in two control plots and two OTC plots in both sampling sites (fen and bog) in June 2008. After 26 months of OTC treatment, in June 2010, 12 peat cores $(25 \mathrm{~cm}$ long) were collected in each plot. The green section of each core $(0-5 \mathrm{~cm} ; 0$ being defined as the top of the Sphagnum capitulum) was discarded during sampling. In the laboratory, the cores were cut into $3 \mathrm{sec}-$ tions (sampling depth): $5-7 \mathrm{~cm}, 7-12 \mathrm{~cm}$ and $12-17 \mathrm{~cm}$.
Samples were stored at $-20^{\circ} \mathrm{C}$. They were then freezedried, powdered with a mortar and pestle and homogenized before lipid extraction and analysis.

\subsection{Sample preparation}

Peat samples were extracted $(3 \times)$ using a modified Bligh and Dyer technique. A solvent mixture $\left(8 \mathrm{ml} \mathrm{g}^{-1}\right.$ of peat 
and extraction step) of $\mathrm{MeOH}$ :dichloromethane (DCM):phosphate buffer at $\mathrm{pH} 7.4(2: 1: 0.8 ; \mathrm{v} / \mathrm{v} / \mathrm{v})$ was added to ca. $1 \mathrm{~g}$ sample in a centrifuge tube, and the mixture placed in an ultrasonic bath (10 min). DCM and phosphate buffer were then added to give a new volume ratio $(1: 1: 0.9, \mathrm{v} / \mathrm{v} / \mathrm{v})$. Each extraction was followed by centrifugation (10 min, $3500 \mathrm{rpm}$ ) and all extracts were collected in a separation funnel. The DCM layer was separated from the $\mathrm{MeOH} /$ phosphate buffer phase, which was again extracted with DCM $(3 \times)$. The DCM fractions were combined and dried over $\mathrm{Na}_{2} \mathrm{SO}_{4}$.

After evaporation of the solvent, the extract was separated over a $2 \mathrm{~cm}$ diameter silica gel column (with a proportion of $7 \mathrm{~g} \mathrm{SiO}_{2}$, activated at $130{ }^{\circ} \mathrm{C}$ overnight for $0.1 \mathrm{~g}$ lipid extract) preconditioned with dichloromethane, using a procedure modified from Lipp and Hinrichs (2009). Three fractions were prepared: F1 containing apolar lipids $(70 \mathrm{ml}$ DCM), F2 containing CL-GDGTs ( $75 \mathrm{ml}$ DCM/acetone $[2: 1, \mathrm{v} / \mathrm{v}]$ followed by $40 \mathrm{ml} \mathrm{DCM} /$ acetone $[1: 1, \mathrm{v} / \mathrm{v}])$, and F3 containing IPL-GDGTs (10 ml DCM/MeOH [1:1, v/v] and $70 \mathrm{ml} \mathrm{MeOH})$. A small aliquot of the obtained IPL fraction (F3) was analyzed directly using high performance liquid chromatography-atmospheric pressure chemical ionisation-mass spectrometry (HPLC/APCI-MS) to determine any carryover of CLs into the IPL fraction. The analysis showed nearly complete separation of the CLand IPL-GDGTs: on average, only $0.6 \pm 1.0 \%$ of IPLGDGTs were present as CL-GDGTs before acid methanolysis of fraction F3. The rest of the fraction F3 was subjected to acid methanolysis to cleave off the polar head groups of IPL-GDGTs and release the core lipids. It was concentrated under reduced pressure to a residual volume and hydrolysed for $24 \mathrm{~h}$ at $100{ }^{\circ} \mathrm{C}$ in $1 \mathrm{M} \mathrm{HCl} / \mathrm{MeOH}$. The mixture was diluted in $\mathrm{MeOH}$ and rotary evaporated under near vacuum $(3 \times)$ to neutralise the hydrolysed aliquot. After fractionation over the silica column, fraction F2 was directly rotary evaporated. Fraction F2 and the core lipids from fraction $\mathrm{F} 3$ were then dried further under $\mathrm{N}_{2}$, ultrasonically dissolved in hexane:isopropanol $(99: 1, \mathrm{v} / \mathrm{v})$ and centrifuged using an Eppendorf MiniSpin centrifuge (1 min, $7000 \mathrm{rpm})$. The supernatants were collected and analysed by HPLC/MS.

\subsection{GDGT analysis}

HPLC/APCI-MS analysis was performed with an Agilent 1100 series high performance liquid chromatograph equipped with an automatic injector coupled to a PE Sciex API 3000 mass spectrometer. GDGTs were analysed using a procedure modified from Hopmans et al. (2000) and Weijers et al. (2007a). Separation was achieved with a Prevail Cyano column $(2.1 \mathrm{~mm} \times 150 \mathrm{~mm}, 3 \mu \mathrm{m}$; Alltech, Deerifled, IL, USA) thermostated at $30^{\circ} \mathrm{C}$. Injection volume was $10 \mu \mathrm{l}$. GDGTs were first eluted isocratically with $99 \%$ $\mathrm{A} / 1 \% \mathrm{~B}$ for $5 \mathrm{~min}$ ( $\mathrm{A}=$ hexane, $\mathrm{B}=$ isopropanol). The following linear gradient was subsequently used: $99 \% \mathrm{~A} / 1 \% \mathrm{~B}$ to $98 \% \mathrm{~A} / 2 \% \mathrm{~B}$ in $45 \mathrm{~min}$, maintained for $5 \mathrm{~min}$, followed by $98 \% \mathrm{~A} / 2 \% \mathrm{~B}$ to $90 \% \mathrm{~A} / 10 \% \mathrm{~B}$ in $1 \mathrm{~min}$, maintained for $10 \mathrm{~min}$ and then back to $99 \% \mathrm{~A} / 1 \% \mathrm{~B}$ in $1 \mathrm{~min}$, maintained for $10 \mathrm{~min}$. The flow rate was set at $0.2 \mathrm{ml} / \mathrm{min}$.
Detection was performed using positive-ion APCI. Ion scanning was performed in pseudo single ion monitoring (SIM) mode, i.e. scanning was from $\mathrm{m} / \mathrm{z} 1015$ to 1025 , 1030 to 1040 and 1044 to 1054 for the detection of the $[\mathrm{M}+\mathrm{H}]^{+}$ions of bacterial GDGTs I, II and III, respectively (Fig. 1). Quantification was achieved by using an internal standard (Fig. 1) synthesised according to Svenson and Thompson (1998). A solution of the internal standard $(0.02 \mathrm{mg} / \mathrm{ml})$ was added to each sample at the end of its preparation for HPLC/MS analysis. Typically, $1 \mu \mathrm{g}$ internal standard was added to $1 \mathrm{mg}$ of the fractions F2 and F3 obtained after separation of the total lipid extract over the silica column. A correction for the different ionisation efficiency of the internal standard vs. the GDGTs was not applied, implying that semi-quantitative data were obtained. Based on duplicate HPLC/MS analyses, the HPLC/MS analysis error for GDGT quantification with the internal standard was ca. $10 \%$.

The MBT and CBT indices were calculated as follows (Weijers et al., 2007a):

$\mathrm{MBT}=\frac{[\mathrm{Ia}+\mathrm{Ib}+\mathrm{Ic}]}{[\mathrm{Ia}+\mathrm{Ib}+\mathrm{Ic}]+[\mathrm{IIa}+\mathrm{II} b+\text { IIc }]+[\mathrm{IIIa}+\mathrm{III} b+\text { IIIc }]}$

$\mathrm{CBT}=-\log \left(\frac{[\mathrm{Ib}]+[\mathrm{IIb}]}{[\mathrm{Ia}]+[\mathrm{IIa}]}\right)$

The Roman numerals correspond to the structures in Fig. 1. Average duplicate errors for the MBT and CBT indices are 0.004 and 0.03 respectively.

Mean annual air temperature (MAAT) and $\mathrm{pH}$ were estimated from the MBT and CBT indices using the equations of Weijers et al. (2007a):

$$
\begin{aligned}
& \mathrm{MBT}=0.122+(0.187 \times \mathrm{CBT})+(0.020 \times \mathrm{MAAT}) \\
& \mathrm{CBT}=3.33-(0.38 \times \mathrm{pH})
\end{aligned}
$$

In some samples, GDGTs Ib and/or IIb were not detected and the CBT could not be calculated. MAAT was therefore also estimated from MBT and $\mathrm{pH}$ using the following equation (Weijers et al., 2007a):

$\mathrm{MBT}=0.867-(0.096 \times \mathrm{pH})+(0.021 \times \mathrm{MAAT})$

\subsection{Statistical analysis}

The differences induced by the OTC treatment in the control and OTC plots, in terms of air and soil temperatures as well as branched GDGT distribution and abundance, were analyzed using the $t$-test (Microsoft Excel Analysis ToolPak). Statistical significance was considered as $p<0.05$; $p$-values between 0.05 and 0.010 were considered as indicating a trend.

\section{RESULTS}

\subsection{Effect of OTCs on air and soil temperature}

In order to assess the effects of the OTCs on air and soil temperature, daily average temperatures as well as minimum and maximum daily temperatures were calculated 
from November 2008 to December 2010. Average, minimum and maximum temperatures were then determined for the whole period, as well as for the winter (DecemberFebruary), spring (March-May), summer (June-August) and autumn (September-November) seasons covering these 26 months (Table 1).

In summer, the daily average air temperature was significantly higher $(p<0.015)$ in the OTCs than in the control plots (average increase of $1.2^{\circ} \mathrm{C}$ at the bog site and $1.0^{\circ} \mathrm{C}$ at the fen site). A similar trend was observed for maximum air temperature (average increase of $3.3^{\circ} \mathrm{C}$ at the bog site and $3.7^{\circ} \mathrm{C}$ at the fen site; $p<0.0001$ ). In contrast, the OTC treatment had no significant effect on the minimum air temperature. Therefore, the increase in mean air temperature can be viewed as a result of the rise in maximal air temperature.

The OTC treatment had a significant effect in the summer average soil temperature at the fen site only (average decrease of $0.7^{\circ} \mathrm{C} ; p=0.0001$ ). During this period, a signif- icant increase of the daily maximum soil temperature was recorded at the bog site (mean $1.4{ }^{\circ} \mathrm{C} ; p<3 \times 10^{-7}$ ), whereas the OTCs significantly decreased the maximum soil temperature at the fen site (mean $2.5^{\circ} \mathrm{C} ; p<2 \times 10^{-19}$ ). The minimum soil temperatures reached lower values in OTCs at both sites (average decrease of $1.4^{\circ} \mathrm{C}$ at the bog site and $0.5^{\circ} \mathrm{C}$ at the fen site; $p \leqslant 0.05$ ), which might be explained by a greater extent of evapotranspiration in OTCs, as discussed later in Section 4.1. In addition, average and maximum soil temperatures were observed to be significantly lower in the control plots of the bog site than in those of the fen site $(p<0.0001)$, whereas maximum soil temperature was significantly higher in the OTC plots of the bog site than in those of the fen site $(p=0.0002)$.

In spring, no significant effect of the OTCs on the average and minimum air and soil temperatures was detected. Nevertheless, as also observed in summer, the OTCs significantly increased the maximum air temperature at both sites (mean of $3.4{ }^{\circ} \mathrm{C}$ at the bog site and $3.0^{\circ} \mathrm{C}$ at the fen site;

Table 1

Average, maximum and minimum daily air (10 cm above soil surface) and soil ( $7 \mathrm{~cm}$ depth) temperatures measured at bog and fen sites from November 2008 to December 2010. Values were calculated for the whole period (2008-2010) as well as for winter (December-February), spring (March-May), summer (June-August) and autumn (September-November). Mean values are given. $p$-Values from $t$-test are listed under the means; those which are significantly different at the 0.05 level are bold and italicized. Whole period: $n=501$ for air temperature and 786 for soil temperature; winter: $n=121$ for air temperature and 211 for soil temperature; spring: $n=134$ for air temperature and 184 for soil temperature; summer: $n=134$ for air temperature and 184 for soil temperature; autumn: $n=154$ for air temperature and 207 for soil temperature.

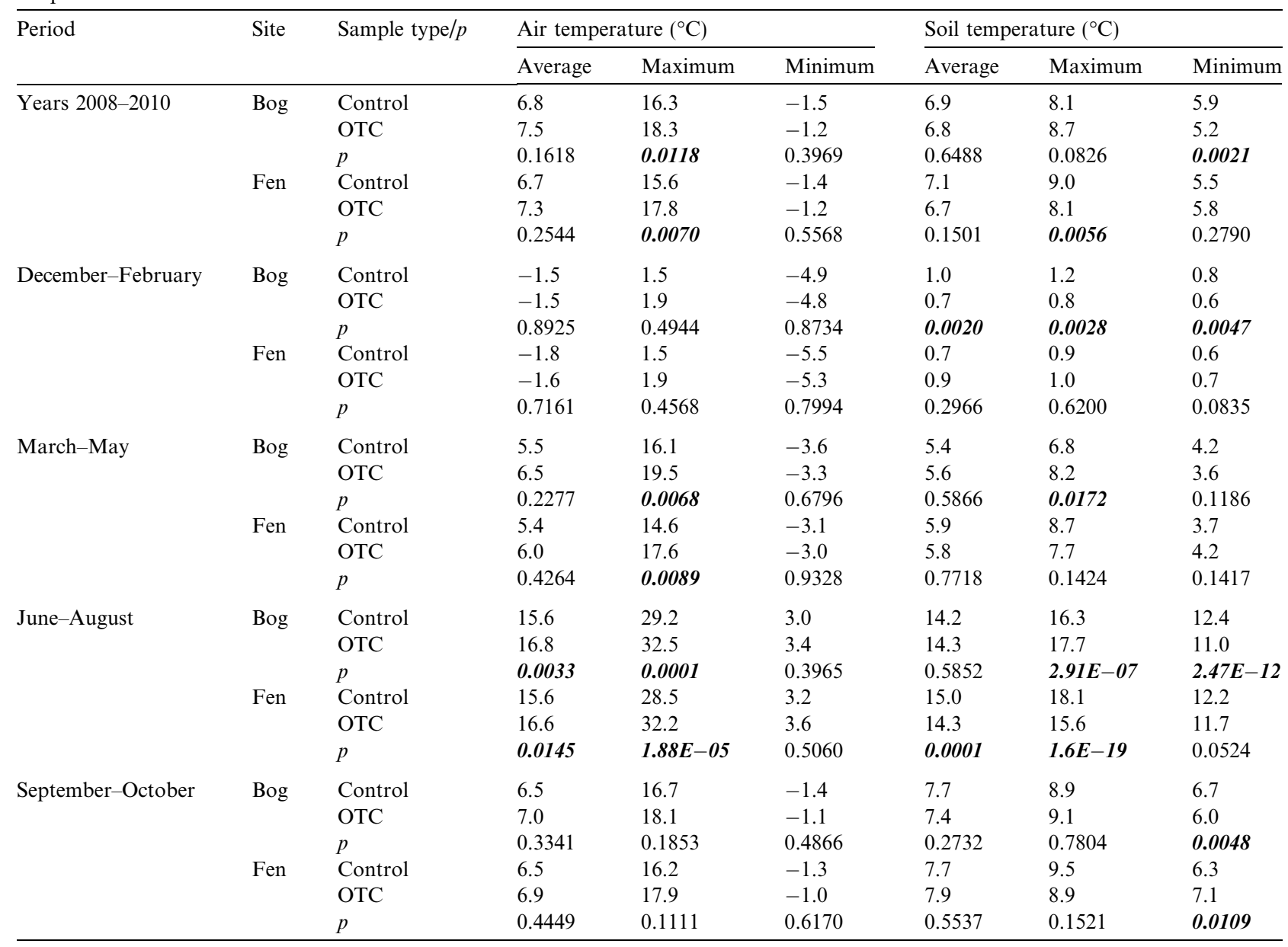


$p<0.01)$ and led to a significant increase in maximum soil temperature at the bog site (mean $1.4{ }^{\circ} \mathrm{C} ; p<0.02$ ).

In autumn (September-November) and winter (December-February), average, maximum and minimum air temperatures were not significantly affected by the OTC treatment (Table 1). Similarly, the average and maximum soil temperatures were not significantly different in the OTC and control plots in autumn. Nevertheless, during this season, the minimum soil temperature was significantly affected by the OTCs (average decrease of $0.7^{\circ} \mathrm{C}$ at the bog site and average increase of $0.5^{\circ} \mathrm{C}$ at the fen site; $p<0.01$ ). In winter, a significant decrease of the average, maximum and minimum soil temperatures was induced by the OTCs at the bog site (average decrease between 0.2 and $0.4{ }^{\circ} \mathrm{C} ; p<0.005$ ), whereas no effect of the OTCs on soil temperature was detected at the fen site. It should be noted that average, minimum and maximum soil temperatures were significantly higher in the control plots of the bog site than in those of the fen site $(p<0.025)$.

Over the whole period (November 2008 - December 2010), the OTC treatment significantly increased the daily maximum air temperature (average of $2{ }^{\circ} \mathrm{C}$ at the bog site and $1.8^{\circ} \mathrm{C}$ at the fen site; $p<0.0120$ ). It also had a significant effect on the daily maximum soil temperature at the fen site (average decrease of $0.9^{\circ} \mathrm{C} ; p<0.01$ ) and on the daily minimum soil temperature at the bog site (average decrease of $\left.0.7^{\circ} \mathrm{C} ; p=0.002\right)$.

\subsection{Analysis of branched GDGTs}

\subsubsection{Identification of GDGTs}

HPLC/MS analysis showed that branched and isoprenoid GDGTs were present in all peat samples (Fig. 5), even though archaeal GDGTs were much less abundant than branched GDGTs. The rest of the paper will be focused on branched GDGTs. The absolute and relative abundances of these compounds were determined in the core and intact polar lipid fractions of all peat samples collected in June 2008 (Fig. 6a; Supplementary Table 1) and June 2010 (Fig. 7; Supplementary Table 2). Branched GDGT CLs represented between ca. $70 \%$ and $90 \%$ of the total pool (i.e. CL + IPL) of branched GDGTs (e.g. Fig. 7b for 2010 samples). GDGTs Ia and IIa were largely predominant among branched GDGTs in the CL and IPL fractions, representing respectively about $50-60 \%$ and $35-40 \%$ of total branched GDGTs (Supplementary Tables 1 and 2). GDGT IIIa was present in lower abundance (about 5\%) than GDGTs Ia and IIa. Branched GDGTs containing one or two cyclopentyl moieties (Ib-IIIb and Ic-IIIc) were much less abundant than corresponding GDGTs without cyclopentyl moieties (Ia-IIIa) as previously observed (Weijers et al., 2007a; Huguet et al., 2010b) and were even not detected in some of the samples. GDGT IIIc was not detected in any of the samples.

\subsubsection{Abundance and distribution of branched GDGTs in peat samples collected in 2008}

The abundance and distribution of branched GDGT CLs and IPLs were first determined in peat samples collected in April 2008. The amount of branched GDGT
CLs (Fig. 6a) was observed to increase with depth at both bog and fen sites $\left(3-8 \mu \mathrm{g} \mathrm{g}^{-1}\right.$ dry weight peat at $5-7 \mathrm{~cm}$ depth vs. $12-18 \mu \mathrm{g} \mathrm{g}^{-1}$ at $12-17 \mathrm{~cm}$ depth). Similarly, the abundance of branched GDGT IPLs was higher at 12$17 \mathrm{~cm}$ depth $\left(2-3 \mu \mathrm{g} \mathrm{g}^{-1}\right)$ than at $5-7 \mathrm{~cm}$ depth $(0.5-$ $1 \mu \mathrm{g} \mathrm{g}^{-1}$; Supplementary Table 1$)$. The relative proportion of the different branched GDGTs was similar in (i) the CL and IPL fractions and (ii) in bog and fen sites, whatever the depth (Supplementary Table 1). This is especially reflected in the MBT index, which presented similar values (ca. 0.55) in both sites, whatever the depth (Fig. 6b).

In order to statistically compare the data from the control and OTC plots at the beginning of the OTC treatment, the values from (i) the fen and bog control plots on one hand and (ii) those from the fen and bog OTC plots on the other hand were pooled (Tables 2 and 3). For both types of lipids (CLs and IPLs), there was no significant difference in absolute branched GDGT concentrations between the control and OTC plots ( $p>0.05$; Table 2). In the same way, the relative abundance of branched GDGT CLs with respect to total extractable GDGTs did not significantly differ between the control and OTC plots $(p>0.05$; Table 2).

The relative proportion of the different branched GDGTs was generally similar in the control and OTC plots for both CLs and IPLs ( $p>0.05$; Table 2). Nevertheless, some slight differences were observed. Thus, at $7-12 \mathrm{~cm}$ depth, the relative abundance of GDGT Ic in the IPL fraction was higher in the control (mean $2.1 \%$ ) than in the OTC plots (mean $1.3 \% ; p=0.043$ ). At $5-7 \mathrm{~cm}$ depth, the relative abundance of GDGT IIa was lower in the OTC than in the control plots for both CL and IPLs $(p<0.04$; Table 2), whereas the relative abundance of GDGT IIb in the CL fraction was higher in the control than in the OTC plots $(p=0.02$; Table 2).

The MBT and CBT indices were observed not to differ significantly between the control and OTCs plots for both CL and IPLs (Table 3), except at 5-7 cm depth, where the CBT was higher in the OTC (mean 1.37) than in the control plots (mean $1.19 ; p=0.037$ ) for the CL fraction. This is reflected in the branched GDGT-derived temperature and $\mathrm{pH}$ estimates, which were not statistically different between the two types of plots, except at 5-7 cm depth (Table 3).

\subsubsection{Abundance and distribution of branched GDGTs in peat samples collected in 2010}

In June 2010, peat samples were collected in the twelve plots. We compare below the abundance and distribution of branched GDGT CLs and IPLs in the two sampling sites (fen and bog) at the three different depths (5-7, 7-12 and $12-17 \mathrm{~cm}$ ) after 26 months of climate warming experiment.

3.2.3.1. Comparison of branched GDGT distribution and abundance between fen and bog sites. Concentrations of branched GDGT CLs (Fig. 7a) and IPLs (Supplementary Table 2) were in the same range of values at the bog and fen sites ( $p>0.05$; values not shown), except at $12-17 \mathrm{~cm}$ depth, where branched GDGT CLs were significantly $(p=0.041)$ more abundant in the bog (mean $10.5 \mu \mathrm{g} \mathrm{g}^{-1}$ dry weight peat) than in the fen plots (mean $7.5 \mu \mathrm{g} \mathrm{g}^{-1}$ ). 


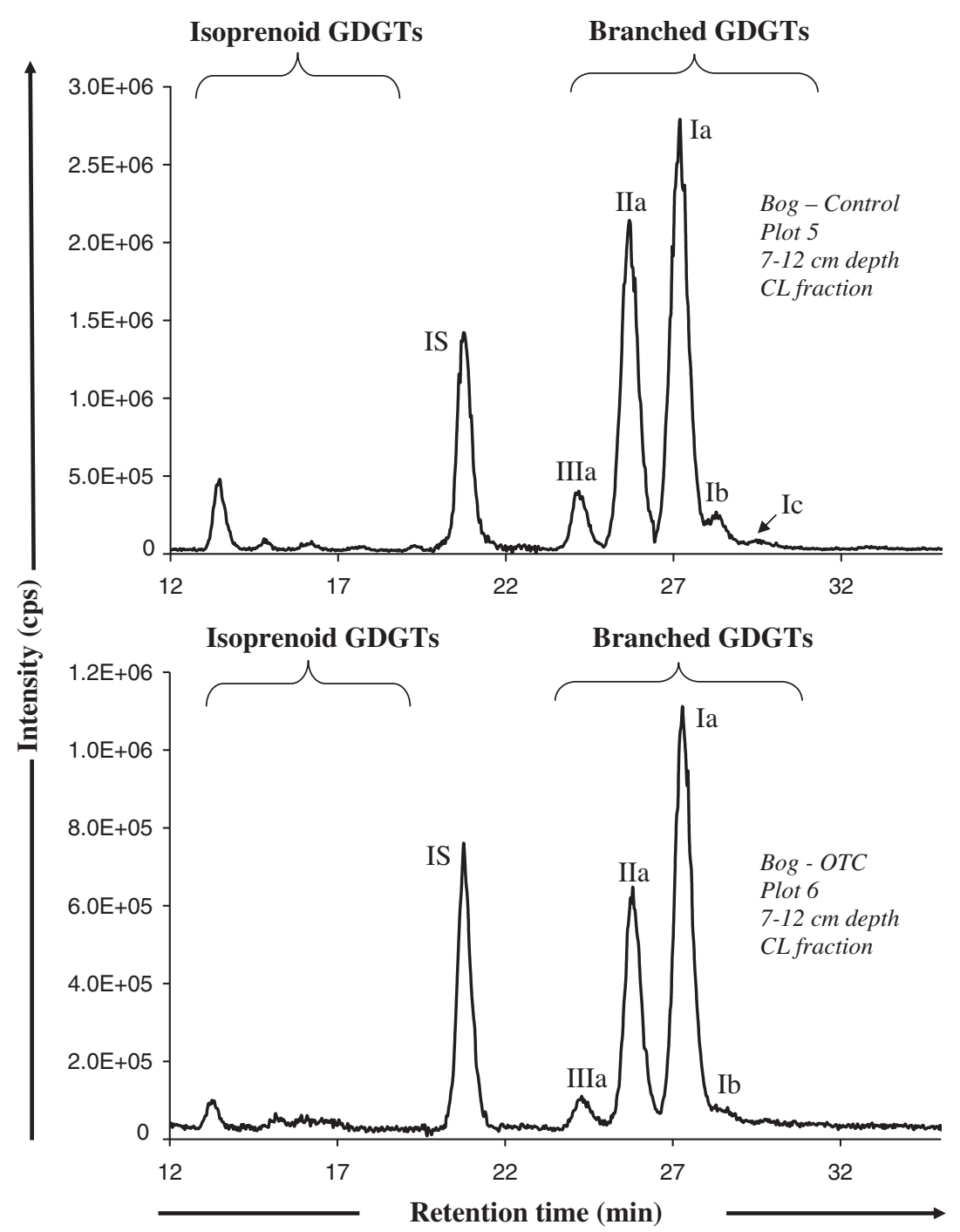

Fig. 5. HPLC/MS base peak chromatograms for bog samples collected in June 2010 in control and OTC plots 5 and 6 respectively showing isoprenoid and branched GDGT distributions in the core lipid (CL) fraction.

For both types of lipids (CLs and IPLs), there was no significant difference in the relative proportion of the different GDGTs between the control plots of the fen and bog sites $(p>0.05$; values not shown). This is reflected in the MBT and CBT values, which did not differ significantly between the control plots of the fen and bog sites, whatever the depth ( $p>0.05$; Fig. 8). It should be noted that GDGTs $\mathrm{Ib}$ and/or IIb were not detected in samples collected at 5$7 \mathrm{~cm}$ depth, preventing determination of the CBT. In contrast, some differences in the distribution of branched GDGT CLs were observed between the OTC plots, at specific depths. Thus, at 5-7 $\mathrm{cm}$ depth, the relative abundance of branched GDGT Ia was significantly higher in the OTC plots of the fen site than in those of the bog site (average of $58 \%$ at the bog site and $66 \%$ at the fen site; $p=0.013$ ). The opposite was observed for GDGT IIa, for which the relative abundance was significantly lower in the OTC plots of the fen site than in those of the bog site, at both 5$7 \mathrm{~cm}$ (average of $35 \%$ at the bog site and $30 \%$ at the fen site; $p=0.009$ ) and $7-12 \mathrm{~cm}$ depth (average of $34 \%$ at the bog site and $30 \%$ at the fen site; $p=0.010$ ). These differences were reflected in the MBT index, which was significantly higher $(p=0.028)$ at $5-7 \mathrm{~cm}$ depth in the OTC plots of the fen site than in those of the bog site $(0.67$ at the fen site vs. 0.61 at the bog site; Fig. 8a). At $7-12$ and $12-17 \mathrm{~cm}$ depth, the MBT and CBT did not differ significantly between the OTC plots of the bog and fen sites (Fig. 8). Whatever the depth, the distribution of branched GDGT IPLs and the corresponding MBT and CBT values did not differ significantly $(p>0.05)$ between the bog and fen OTC plots.

3.2.3.2. Variation of branched GDGT distribution and abundance with depth. The amount of branched GDGT CLs was significantly higher $(p<0.0005)$ at $12-17 \mathrm{~cm}$ depth (about $8-10 \mu \mathrm{g} \mathrm{g}^{-1}$ dry weight peat) than at 5-7 $\mathrm{cm}$ (about $1 \mu \mathrm{g} \mathrm{g}^{-1}$; Fig. 7a), whatever the site. In the same way, the abundance of branched GDGT IPLs was observed to significantly increase with depth $(p<0.004)$ at both bog and 

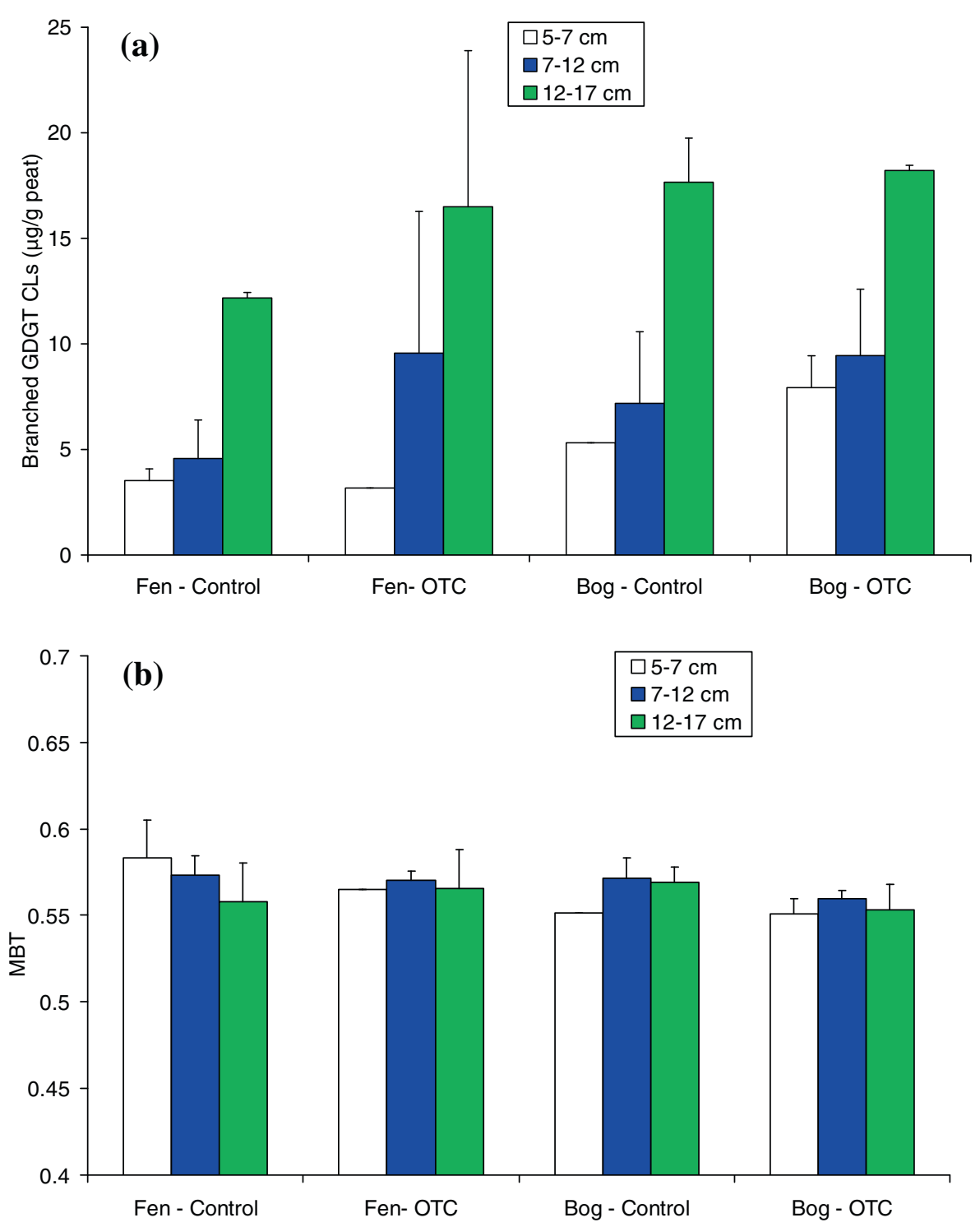

Fig. 6. (a) Concentration of branched GDGT core lipids (CL) in OTC and control plots from bog and fen sites for samples collected in April 2008. GDGT concentrations are expressed in $\mu \mathrm{g} \mathrm{g}^{-1}$ dry wt. peat. (b) Mean values and standard errors of methylation index (MBT) of branched GDGT CLs in OTC and control plots from bog and fen sites (April 2008; $n=2$ ).

fen sites, from ca. $0.4 \mu \mathrm{g} \mathrm{g}^{-1}$ at 5-7 $\mathrm{cm}$ depth to ca. $2 \mu \mathrm{g} \mathrm{g}^{-1}$ at $12-17 \mathrm{~cm}$ depth (Supplementary Table 2).

The relative abundance of the different branched GDGTs varied with depth. Indeed, at the fen site, the MBT decreased with depth in both control and OTC plots, as shown in Fig. 8a for branched GDGT CLs. A similar trend was observed at the bog site, even though the MBT increased between $5-7 \mathrm{~cm}$ and $7-12 \mathrm{~cm}$ depth for OTC plots (Fig. 8a). In addition, the CBT was systematically higher at $7-12 \mathrm{~cm}$ than at $12-17 \mathrm{~cm}$ depth, whatever the site (fen or bog; Fig. 8b).

\subsubsection{Effect of the OTC treatment on branched GDGT} distribution and abundance. As indicated above, there was generally no significant difference in branched GDGT distribution and abundance between the fen and bog sites, ex- cept at 5-7 $\mathrm{cm}$ depth, where the distribution of branched GDGTs slightly differed between the OTC plots of the bog and fen sites. Therefore, in order to investigate more specifically the impact of the OTC treatment on branched GDGT distribution and abundance, we combined the data obtained at bog and fen sites, i.e. we pooled the values from (i) the fen and bog control plots on one hand and (ii) those from the fen and bog OTC plots on the other hand (Tables 4 and 5).

The absolute concentrations of branched GDGT CLs and IPLs did not show any significant differences between OTCs and control plots (Table 4). In the same way, the abundance of branched GDGT CLs with respect to total extractable (i.e. CLs + IPLs) branched GDGTs did not vary significantly between OTCs and control plots, even though the proportion of branched GDGT CLs was 

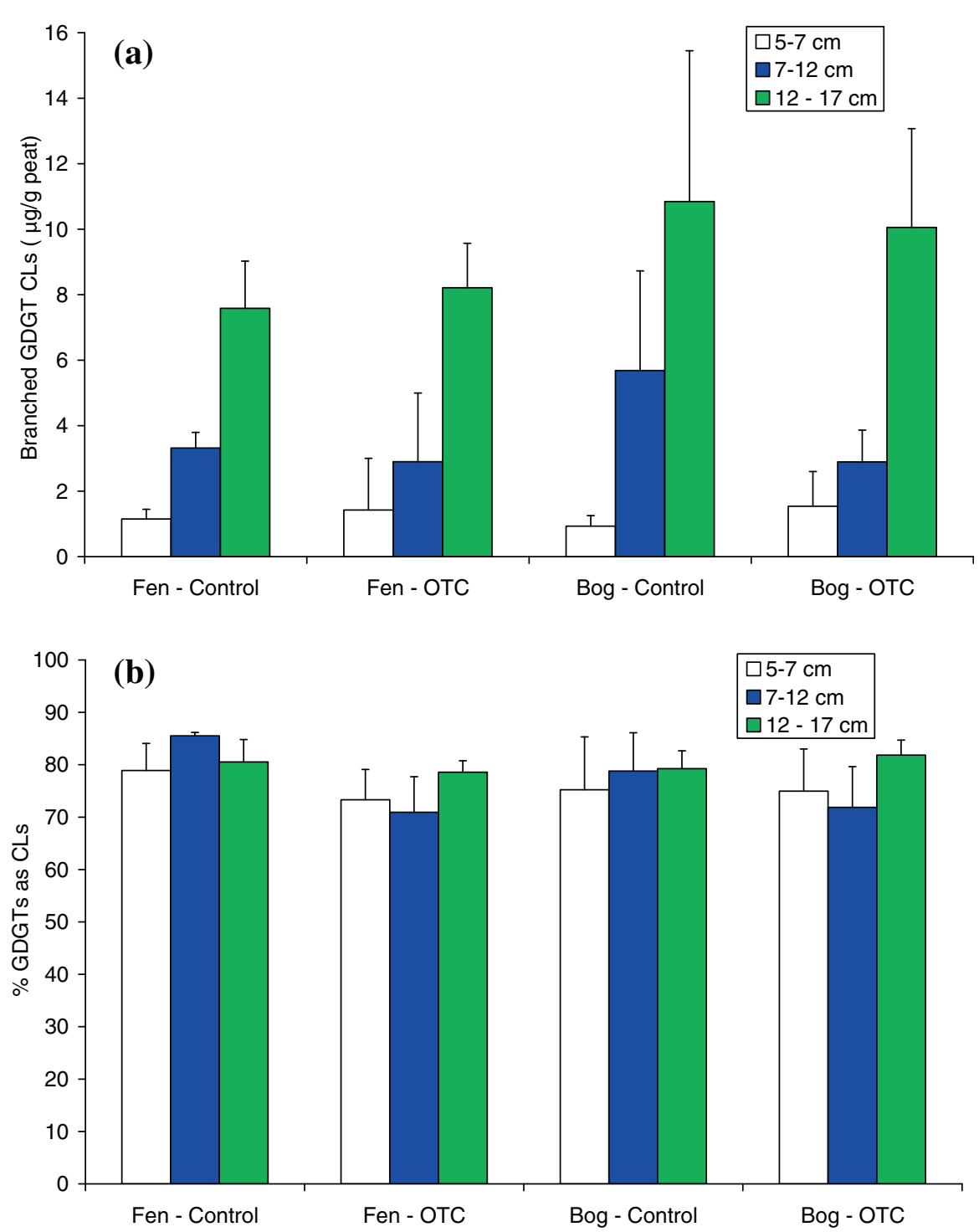

Fig. 7. (a) Concentration of branched GDGT core lipids (CL) in OTC and control plots from bog and fen sites for samples collected in June 2010. GDGT concentrations are expressed in $\mu \mathrm{g} \mathrm{g}^{-1}$ dry wt. peat. (b) Relative abundance of branched GDGT CLs with respect to total extractable (i.e. core + intact polar) branched GDGTs for samples collected in June 2010.

slightly lower in OTCs (mean $71 \%$ ) than in control plots (mean $82 \%$; Table 4) at 7-12 cm depth .

The OTC treatment induced some significant changes in the relative abundance of the different branched GDGT CLs, as shown by HPLC chromatograms of samples from the bog site (Fig. 5). Thus, the relative abundance of GDGT Ia was significantly higher in the OTCs than in the control plots (Table 4). The opposite pattern was observed for GDGT IIa, with a lower relative abundance in the OTCs than in the control plots (Table 4). Additionally, the relative abundance of GDGT IIIa was significantly lower in OTCs than in control plots at $12-17 \mathrm{~cm}$ depth. The relationship observed in the study between GDGTs Ia and IIa on the one hand and temperature on the other hand (i.e. increased temperature resulting in higher and lower relative abundances of GDGTs Ia and IIa respectively) are similar to those previously observed in other environments such as soils (e.g. Weijers et al., 2007a; Huguet et al., 2010a), peats (e.g. Huguet et al., 2010b; Weijers et al., 2011a) and lakes (e.g. Tierney et al., 2010; Pearson et al., 2011). The modifications in branched GDGT distribution induced by the OTC treatment in the Frasne peatland were reflected in the MBT index, which was significantly higher in the OTCs at all depths (Table 5). In contrast, statistical analysis did not show any significant difference in CBT index between the OTCs and control plots (Table 5).

The distribution of branched GDGT IPLs was also impacted by the OTC treatment. Indeed, GDGT Ia was significantly higher in the OTCs than in the control plots at 7 $12 \mathrm{~cm}$ depth (Table 4). In addition, as also observed for branched GDGT CLs, the relative abundance of GDGT IIa was significantly lower in the OTCs (Table 4), and the MBT exhibited lower values in the control plots than in the OTCs at all depths (Table 5). 
Table 2

Means and standard errors of the relative abundances of the different branched GDGTs, branched GDGT concentrations (expressed ng $\mathrm{g}^{-1}$ dry wt. peat) and relative abundances of core vs. total extractable (i.e. core + intact polar) branched GDGTs (n.d., not detected) for peat samples collected in April 2008. At each depth, data from (i) fen and bog control plots on one hand and (ii) fen and bog OTC plots on the other hand were combined $(n=4)$. All the parameters were determined in the core and intact polar lipid (IPL) fractions. $p$-Values from $t$-test for each of the parameters are listed under the means; those which are significantly different at the 0.05 level are bold and italicized.

\begin{tabular}{|c|c|c|c|c|c|c|c|c|c|c|c|}
\hline \multirow[t]{2}{*}{ Depth } & \multirow[t]{2}{*}{ Fraction } & \multirow{2}{*}{$\begin{array}{l}\text { Sample } \\
\text { type/p }\end{array}$} & \multicolumn{7}{|c|}{ Relative abundance $(\%)$} & \multirow{2}{*}{$\begin{array}{l}\text { Branched } \\
\text { GDGT } \\
\text { concentration } \\
\left(\mathrm{ng} \mathrm{g}^{-1}\right)\end{array}$} & \multirow{2}{*}{$\begin{array}{l}\text { Relative } \\
\text { abundance } \\
\text { CLs vs. total } \\
\text { GDGTs (\%) }\end{array}$} \\
\hline & & & Ia & $\mathrm{Ib}$ & Ic & IIa & $\mathrm{Ib}$ & Ic & $\mathrm{Ia}$ & & \\
\hline$n$ & $\mathrm{CL}$ & $\begin{array}{l}\text { Control } \\
\text { OTC } \\
p \\
\text { Control } \\
\text { OTC } \\
p\end{array}$ & $\begin{array}{l}52.5 \pm 2.0 \\
51.1 \pm 0.5 \\
0.1415 \\
50.7 \pm 3.7 \\
45.0 \pm 5.0 \\
0.1229\end{array}$ & $\begin{array}{l}4.6 \pm 0.9 \\
4.2 \pm 1.5 \\
0.3403 \\
1.7 \pm 0.5 \\
2.4 \pm 1.9 \\
0.2620\end{array}$ & $\begin{array}{l}0.9 \pm 0.2 \\
1.0 \\
\text { n.d. } \\
\text { n.d. } \\
\text { n.d. } \\
\text { n.d. }\end{array}$ & $\begin{array}{l}33.7 \pm 2.0 \\
38.6 \pm 0.6 \\
\boldsymbol{0 . 0 0 4 7} \\
33.6 \pm 1.5 \\
36.5 \pm 2.1 \\
\boldsymbol{0 . 0 4 1 1}\end{array}$ & $\begin{array}{l}1.0 \pm 0.2 \\
0.5 \pm 0.2 \\
\boldsymbol{0 . 0 2 0 0} \\
1.9 \pm 1.0 \\
1.5 \pm 0.6 \\
0.3108\end{array}$ & $\begin{array}{l}2.6 \pm 1.6 \\
1.08 \\
\text { n.d. } \\
\text { n.d. } \\
5.1 \\
\text { n.d. }\end{array}$ & $\begin{array}{l}4.7 \pm 0.9 \\
5.1 \pm 1.2 \\
0.2842 \\
8.0 \pm 3.6 \\
7.0 \pm 0.2 \\
0.3248\end{array}$ & $\begin{array}{l}3976 \pm 1000 \\
6343 \pm 2950 \\
0.0925 \\
763 \pm 452 \\
903 \pm 257 \\
0.3274\end{array}$ & $\begin{array}{l}84.1 \pm 7.5 \\
86.7 \pm 3.1 \\
0.3054\end{array}$ \\
\hline $\mathrm{m}$ & $\mathrm{CL}$ & $\begin{array}{l}\text { Control } \\
\text { OTC } \\
p \\
\text { Control } \\
\text { OTC } \\
p\end{array}$ & $\begin{array}{l}52.4 \pm 1.7 \\
52.4 \pm 2.4 \\
0.4757 \\
51.1 \pm 2.9 \\
48.5 \pm 2.8 \\
0.1029\end{array}$ & $\begin{array}{l}4.0 \pm 0.7 \\
3.6 \pm 1.5 \\
0.3022 \\
3.9 \pm 1.2 \\
4.5 \pm 1.2 \\
0.2476\end{array}$ & $\begin{array}{l}1.0 \pm 0.5 \\
0.5 \pm 0.4 \\
0.0896 \\
2.1 \pm 0.2 \\
1.3 \pm 0.6 \\
\boldsymbol{0 . 0 4 3 4}\end{array}$ & $\begin{array}{l}37.0 \pm 1.7 \\
36.2 \pm 1.6 \\
0.2545 \\
37.2 \pm 1.6 \\
37.8 \pm 1.6 \\
0.2907\end{array}$ & $\begin{array}{l}0.5 \pm 0.2 \\
0.8 \pm 0.6 \\
0.1347 \\
1.4 \pm 0.8 \\
1.3 \pm 0.5 \\
0.4087\end{array}$ & $\begin{array}{l}1.5 \pm 0.5 \\
1.0 \pm 0.9 \\
0.2256 \\
\text { n.d. } \\
0.7 \pm 0.2 \\
\text { n.d. }\end{array}$ & $\begin{array}{l}5.4 \pm 0.7 \\
4.3 \pm 1.3 \\
0.0664 \\
6.4 \pm 1.6 \\
6.6 \pm 1.7 \\
0.4011\end{array}$ & $\begin{array}{l}5614 \pm 2570 \\
9505 \pm 4282 \\
0.0664 \\
1300 \pm 592 \\
2361 \pm 1345 \\
0.0766\end{array}$ & $\begin{array}{l}81.1 \pm 3.4 \\
80.5 \pm 4.2 \\
0.4208\end{array}$ \\
\hline$-1 / \mathrm{cm}$ & IPL & $\begin{array}{l}\text { Control } \\
\text { OTC } \\
p \\
\text { Control } \\
\text { OTC } \\
p\end{array}$ & $\begin{array}{l}50.0 \pm 1.8 \\
51.3 \pm 1.5 \\
0.1649 \\
48.5 \pm 3.5 \\
48.3 \pm 2.4 \\
0.4781\end{array}$ & $\begin{array}{l}5.0 \pm 1.4 \\
4.3 \pm 1.4 \\
0.2388 \\
4.7 \pm 1.5 \\
4.6 \pm 1.3 \\
0.4512\end{array}$ & $\begin{array}{l}1.3 \pm 0.3 \\
1.0 \pm 0.1 \\
0.0503 \\
2.6 \pm 0.5 \\
2.3 \pm 0.8 \\
0.2632\end{array}$ & $\begin{array}{l}37.8 \pm 1.0 \\
37.2 \pm 1.5 \\
0.2558 \\
36.2 \pm 0.9 \\
35.9 \pm 1.0 \\
0.3573\end{array}$ & $\begin{array}{l}0.6 \pm 0.2 \\
0.5 \pm 0.1 \\
0.3048 \\
1.6 \pm 0.8 \\
2.3 \pm 0.6 \\
0.1311\end{array}$ & $\begin{array}{l}0.6 \pm 0.3 \\
0.8 \pm 0.2 \\
0.1761 \\
0.8 \\
1.2 \pm 0.7 \\
\text { n.d. }\end{array}$ & $\begin{array}{l}4.7 \pm 0.6 \\
5.6 \pm 1.0 \\
0.0860 \\
6.8 \pm 0.5 \\
6.4 \pm 1.6 \\
0.3307\end{array}$ & $\begin{array}{l}14920 \pm 3388 \\
17356 \pm 4382 \\
0.2065 \\
2449 \pm 234 \\
3523 \pm 1513 \\
0.1051\end{array}$ & $\begin{array}{l}85.6 \pm 2.1 \\
83.0 \pm 3.9 \\
0.1408\end{array}$ \\
\hline
\end{tabular}

${ }^{a}$ Several GDGTs were detected in only some of the control/OTC plots, hindering proper statistical analysis. The mean value of these parameters is italicized and the standard error is not given.

Table 3

Means and standard errors of proxy values (MBT and CBT) and of $\mathrm{pH}$ and mean annual air temperature (MAAT) estimates derived from MBT and CBT for peat samples collected in April 2008 (n.d., not determined). At each depth, data from (i) fen and bog control plots on one hand and (ii) fen and bog OTC plots on the other hand were combined $(n=4)$. All the parameters were determined in the CL and IPL fractions. $p$-Values from $t$-test for each of the parameters are listed under the means; those which are significantly different at the 0.05 level are bold and italicized.

\begin{tabular}{|c|c|c|c|c|c|c|c|}
\hline Depth & Fraction & Sample type/ $p$ & MBT & CBT & CBT pH & $\begin{array}{l}\text { MBT/CBT } \\
\text { MAAT }\left({ }^{\circ} \mathrm{C}\right)\end{array}$ & $\begin{array}{l}\text { MBT/pH } \\
\text { MAAT }\left({ }^{\circ} \mathrm{C}\right)\end{array}$ \\
\hline $5-7 \mathrm{~cm}$ & $\mathrm{CL}$ & $\begin{array}{l}\text { Control } \\
\text { OTC } \\
p \\
\text { Control } \\
\text { OTC } \\
p\end{array}$ & $\begin{array}{l}0.57 \pm 0.02 \\
0.56 \pm 0.01 \\
0.1251 \\
0.56 \pm 0.03 \\
0.54 \pm 0.02 \\
0.1269\end{array}$ & $\begin{array}{l}1.19 \pm 0.09 \\
1.37 \pm 0.07 \\
0.0367 \\
1.41 \pm 0.19 \\
1.37 \pm 0.27 \\
0.4220\end{array}$ & $\begin{array}{l}5.6 \pm 0.2 \\
5.3 \pm 0.3 \\
0.1027 \\
5.1 \pm 0.5 \\
5.0 \pm 0.6 \\
0.4158\end{array}$ & $\begin{array}{l}11.5 \pm 1.7 \\
8.6 \pm 0.2 \\
0.04638 \\
9.0 \pm 0.6 \\
8.0 \pm 1.5 \\
0.1311\end{array}$ & $\begin{array}{l}4.3 \pm 2.4 \\
3.8 \pm 1.3 \\
0.3790 \\
3.8 \pm 2.7 \\
3.0 \pm 1.0 \\
0.3156\end{array}$ \\
\hline $7-12 \mathrm{~cm}$ & $\begin{array}{l}\text { CL } \\
\text { IPL }\end{array}$ & $\begin{array}{l}\text { Control } \\
\text { OTC } \\
p \\
\text { Control } \\
\text { OTC } \\
p\end{array}$ & $\begin{array}{l}0.57 \pm 0.01 \\
0.56 \pm 0.01 \\
0.1220 \\
0.56 \pm 0.01 \\
0.54 \pm 0.02 \\
0.0699\end{array}$ & $\begin{array}{l}1.31 \pm 0.16 \\
1.31 \pm 0.22 \\
0.4526 \\
1.24 \pm 0.15 \\
1.18 \pm 0.09 \\
0.2531\end{array}$ & $\begin{array}{l}5.3 \pm 0.2 \\
5.3 \pm 0.3 \\
0.4526 \\
5.5 \pm 0.4 \\
5.7 \pm 0.2 \\
0.2531\end{array}$ & $\begin{array}{l}10.3 \pm 0.5 \\
9.9 \pm 1.2 \\
0.2680 \\
10.1 \pm 1.1 \\
9.8 \pm 0.9 \\
0.3591\end{array}$ & $\begin{array}{l}3.3 \pm 0.4 \\
2.9 \pm 0.7 \\
0.1611 \\
2.5 \pm 0.8 \\
1.7 \pm 0.9 \\
0.0980\end{array}$ \\
\hline $12-17 \mathrm{~cm}$ & IPL & $\begin{array}{l}\text { Control } \\
\text { OTC } \\
p \\
\text { Control } \\
\text { OTC } \\
p\end{array}$ & $\begin{array}{l}0.56 \pm 0.02 \\
0.56 \pm 0.02 \\
0.3681 \\
0.55 \pm 0.01 \\
0.55 \pm 0.02 \\
0.3935\end{array}$ & $\begin{array}{l}1.20 \pm 0.12 \\
1.25 \pm 0.15 \\
0.3230 \\
1.13 \pm 0.13 \\
1.19 \pm 0.24 \\
0.3397\end{array}$ & $\begin{array}{l}5.6 \pm 0.3 \\
5.4 \pm 0.3 \\
0.2272 \\
5.8 \pm 0.4 \\
5.9 \pm 0.3 \\
0.3595\end{array}$ & $\begin{array}{l}10.8 \pm 1.4 \\
10.0 \pm 1.9 \\
0.2541 \\
10.9 \pm 0.9 \\
11.1 \pm 1.4 \\
0.4315\end{array}$ & $\begin{array}{l}2.7 \pm 0.3 \\
3.8 \pm 0.9 \\
0.2917 \\
2.2 \pm 1.1 \\
1.9 \pm 1.0 \\
0.3522\end{array}$ \\
\hline
\end{tabular}



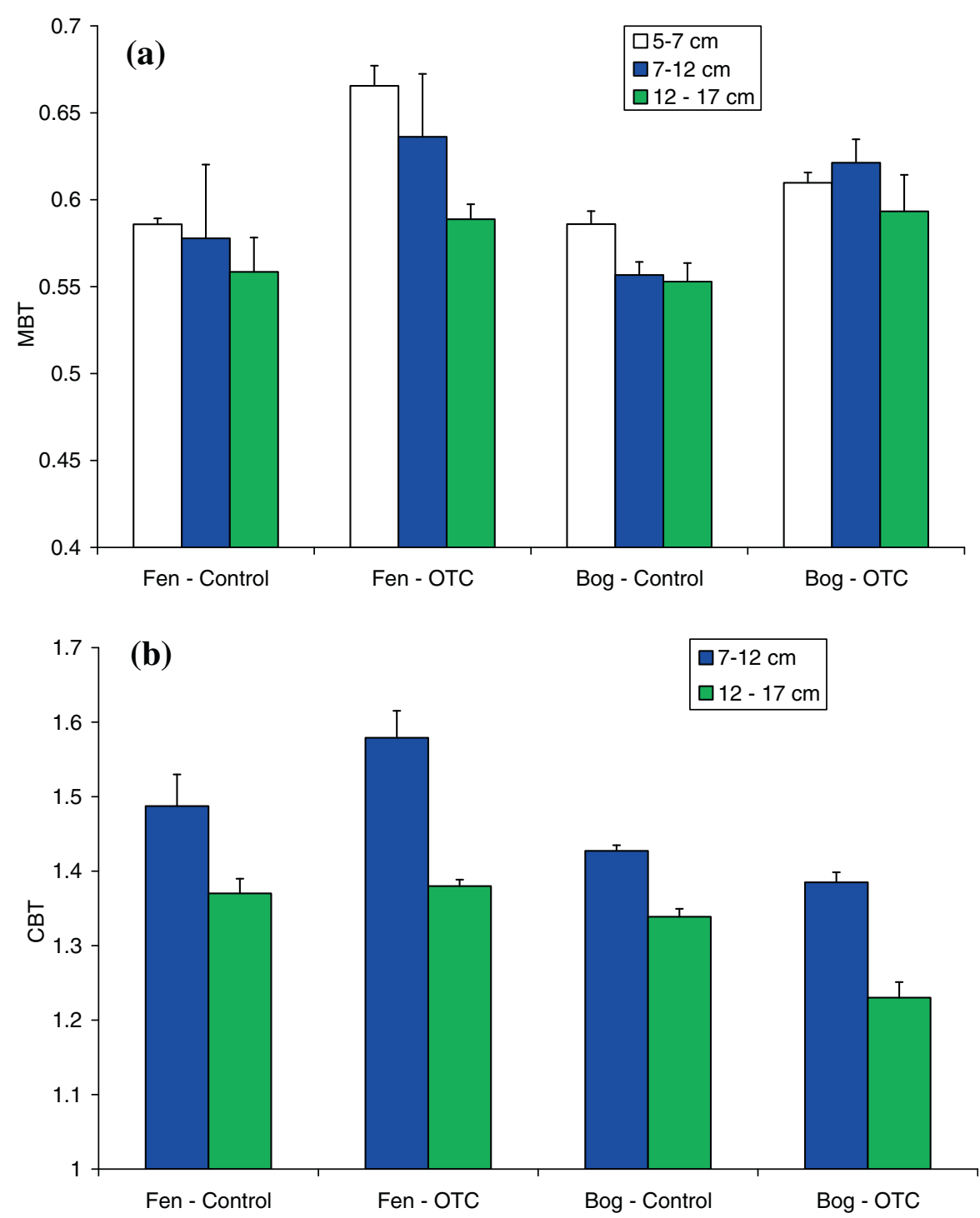

Fig. 8. Mean values and standard errors of (a) methylation index (MBT) and (b) cyclisation ratio (CBT) of branched GDGT CLs in OTC and control plots from bog and fen sites for samples collected in June $2010(n=3)$. The CBT could only be determined at 7-12 and 12-17 cm depth.

Branched GDGT distribution was compared between the CL and IPL fractions. At 5-7 $\mathrm{cm}$ and 7-12 $\mathrm{cm}$ depth, the relative abundance of each branched GDGT as well as the MBT and CBT values were observed not to differ significantly between the CL and IPL fractions in both control and OTC plots $(p>0.05)$. In contrast, at $12-17 \mathrm{~cm}$ depth, some differences were observed between the two lipid fractions. The relative abundance of GDGT Ia and the MBT were higher in the CL than in the IPL fraction for both OTC and control plots (Table 6). In addition, the relative abundances of GDGTs IIa and IIIa were, respectively, significantly lower and higher in the CL than in the IPL fractions for the control plots (Table 6).

\subsection{Reconstruction of air temperature and peat $\mathrm{pH}$}

Peat $\mathrm{pH}$ was reconstructed from the CBT index using Eq. 4. $\mathrm{pH}$ estimates are presented in Supplementary Tables 3 and 4 for peat samples collected in April 2008 and June 2010 respectively. In agreement with the lack of significant difference in CBT between the control and OTC plots for both core and intact polar lipids, CBT-pH estimates do not show significant differences (cf. Tables 3 and 5 for samples collected in 2008 and 2010 respectively). The $\mathrm{pH}$ estimates for samples collected in 2008 were comprised between 5.0 and 5.8 at 5-7 cm depth (mean 5.6; Table 3), 4.9 and 5.8 at $7-12 \mathrm{~cm}$ depth (mean 5.3; Table 3) and 5.2 and 6.0 at $12-17 \mathrm{~cm}$ depth (mean 5.6; Table 3) and overestimated actual pH values (3.6-4.5; Supplementary Table 3). Similarly, $\mathrm{pH}$ values derived from CLs for samples collected in 2010 ranged between 3.9 and 5.6 at $7-12 \mathrm{~cm}$ depth (mean 4.9; Table 5) and between 5.0 and 6.1 (mean 5.2; Table 5) at $12-17 \mathrm{~cm}$ depth and were higher than actual $\mathrm{pH}$ measurements at those depths (3.6-3.9; Supplementary Table 4).

MAAT was estimated from MBT and CBT using Eq. 3 (see Supplementary Tables 3 and 4 for values from samples 
Table 4

Means and standard errors of the relative abundances of the different branched GDGTs, branched GDGT concentrations (expressed ng $\mathrm{g}^{-1}$ dry wt. peat) and relative abundances of core vs. total extractable (i.e. core + intact polar) branched GDGTs for peat samples collected in June 2010 (n.d., not detected). At each depth, data from (i) fen and bog control plots on one hand and (ii) fen and bog OTC plots on the other hand were combined $(n=6)$. All the parameters were determined in the core and intact polar lipid (IPL) fractions. $p$-Values from $t$-test for each of the parameters are listed under the means; those which are significantly different at the 0.05 level are bold and italicized.

\begin{tabular}{|c|c|c|c|c|c|c|c|c|c|c|c|}
\hline \multirow[t]{2}{*}{ Depth } & \multirow[t]{2}{*}{ Fraction } & \multirow{2}{*}{$\begin{array}{l}\text { Sample } \\
\text { type } / p\end{array}$} & \multicolumn{7}{|c|}{ Relative abundance $(\%)$} & \multirow{2}{*}{$\begin{array}{l}\text { Branched } \\
\text { GDGT } \\
\text { concentration } \\
\left(\mathrm{ng} \mathrm{g}^{-1}\right)\end{array}$} & \multirow{2}{*}{$\begin{array}{l}\text { Relative } \\
\text { abundance } \\
\text { CLs vs. total } \\
\text { GDGTs }(\%)\end{array}$} \\
\hline & & & $\overline{\mathrm{Ia}}$ & $\mathrm{Ib}$ & Ic & IIa & $\mathrm{IIb}$ & IIc & IIIa & & \\
\hline \multirow[t]{6}{*}{$5-7 \mathrm{~cm}$} & \multirow[t]{3}{*}{$\mathrm{CL}$} & Control & $57.2 \pm 1.1$ & $1.4^{\mathrm{a}}$ & n.d. & $36.6 \pm 2.6$ & n.d. & n.d. & $4.8 \pm 3.1$ & $1018 \pm 297$ & $76.7 \pm 7.9$ \\
\hline & & OTC & $62.5 \pm 5.1$ & 1.0 & n.d. & $32.3 \pm 3.0$ & n.d. & n.d. & $4.2 \pm 1.7$ & $1482 \pm 1203$ & $74.1 \pm 6.3$ \\
\hline & & $p$ & 0.0259 & n.d. & n.d. & 0.0186 & n.d. & n.d. & 0.3336 & 0.2127 & 0.2822 \\
\hline & \multirow[t]{3}{*}{ IPL } & Control & $58.6 \pm 1.3$ & n.d. & n.d. & $37.5 \pm 5.5$ & n.d. & n.d. & 3.9 & $348 \pm 248$ & \\
\hline & & OTC & $61.8 \pm 5.2$ & 1.4 & n.d. & $32.6 \pm 2.9$ & n.d. & n.d. & 4.2 & $441 \pm 261$ & \\
\hline & & $p$ & 0.1074 & n.d. & n.d. & 0.0453 & n.d. & n.d. & n.d. & 0.2792 & \\
\hline \multirow[t]{6}{*}{$7-12 \mathrm{~cm}$} & \multirow[t]{3}{*}{$\mathrm{CL}$} & Control & $53.2 \pm 3.1$ & $2.9 \pm 1.1$ & 0.4 & $37.3 \pm 1.8$ & $0.4 \pm 0.2$ & 0.4 & $5.4 \pm 0.7$ & $4738 \pm 2523$ & $81.5 \pm 6.3$ \\
\hline & & OTC & $59.8 \pm 3.5$ & $2.7 \pm 1.3$ & 0.2 & $32.1 \pm 2.6$ & $0.6 \pm 0.3$ & 0.4 & $4.3 \pm 1.3$ & $2897 \pm 1460$ & $71.4 \pm 6.5$ \\
\hline & & $p$ & 0.0047 & 0.4061 & n.d. & 0.0002 & 0.2052 & n.d. & 0.0664 & 0.0817 & 0.0148 \\
\hline & \multirow[t]{3}{*}{ IPL } & Control & $52.9 \pm 4.4$ & $3.0 \pm 1.4$ & n.d. & $39.3 \pm 4.0$ & 0.9 & n.d. & $4.0 \pm 1.6$ & $1264 \pm 1073$ & \\
\hline & & OTC & $58.7 \pm 4.3$ & $3.8 \pm 2.2$ & 0.4 & $32.2 \pm 1.2$ & $0.6 \pm 0.4$ & n.d. & $4.2 \pm 1.7$ & $1189 \pm 751$ & \\
\hline & & $p$ & 0.0270 & 0.2622 & n.d. & 0.0012 & n.d. & n.d. & 0.4039 & 0.4478 & \\
\hline \multirow[t]{6}{*}{$12-17 \mathrm{~cm}$} & \multirow[t]{3}{*}{$\mathrm{CL}$} & Control & $50.8 \pm 1.5$ & $3.5 \pm 0.6$ & $1.2 \pm 0.6$ & $36.9 \pm 1.0$ & $0.4 \pm 0.1$ & $0.4 \pm 0.1$ & $6.8 \pm 0.9$ & $9541 \pm 3783$ & $79.8 \pm 3.2$ \\
\hline & & OTC & $53.8 \pm 3.1$ & $4.2 \pm 1.8$ & $0.8 \pm 0.5$ & $35.0 \pm 1.8$ & $0.4 \pm 0.1$ & $0.4 \pm 0.3$ & $5.3 \pm 0.5$ & $9133 \pm 2323$ & $80.2 \pm 2.9$ \\
\hline & & $p$ & 0.0380 & 0.2169 & 0.1092 & 0.0333 & 0.391 & 0.3543 & 0.0035 & 0.4152 & 0.4082 \\
\hline & \multirow[t]{3}{*}{ IPL } & Control & $48.2 \pm 2.5$ & $3.1 \pm 1.1$ & $1.6 \pm 0.9$ & $40.0 \pm 1.6$ & $1.6 \pm 0.7$ & $0.7 \pm 0.1$ & $4.9 \pm 0.8$ & $2528 \pm 1373$ & \\
\hline & & OTC & $50.1 \pm 2.8$ & $4.6 \pm 1.7$ & $1.9 \pm 0.6$ & $35.9 \pm 2.3$ & $0.8 \pm 0.3$ & $0.5 \pm 0.2$ & $5.2 \pm 1.2$ & $2196 \pm 349$ & \\
\hline & & $p$ & 0.1412 & 0.0645 & 0.3836 & 0.0040 & 0.0119 & 0.0169 & 0.3460 & 0.2893 & \\
\hline
\end{tabular}

${ }^{a}$ At 5-7 and 7-12 cm depth, several GDGTs were detected in only some of the control/OTC plots, hindering proper statistical analysis. The mean value of these parameters is italicized and the standard error is not given.

Table 5

Means and standard errors of proxy values (MBT and CBT) and of $\mathrm{pH}$ and mean annual air temperature (MAAT) estimates derived from MBT and CBT for peat samples collected in June 2010 (n.d., not determined). At each depth, data from (i) fen and bog control plots on one hand and (ii) fen and bog OTC plots on the other hand were combined $(n=6)$. All the parameters were determined in the CL and IPL fractions. $p$-Values from $t$-test for each of the parameters are listed under the means; those which are significantly different at the 0.05 level are bold and italicized.

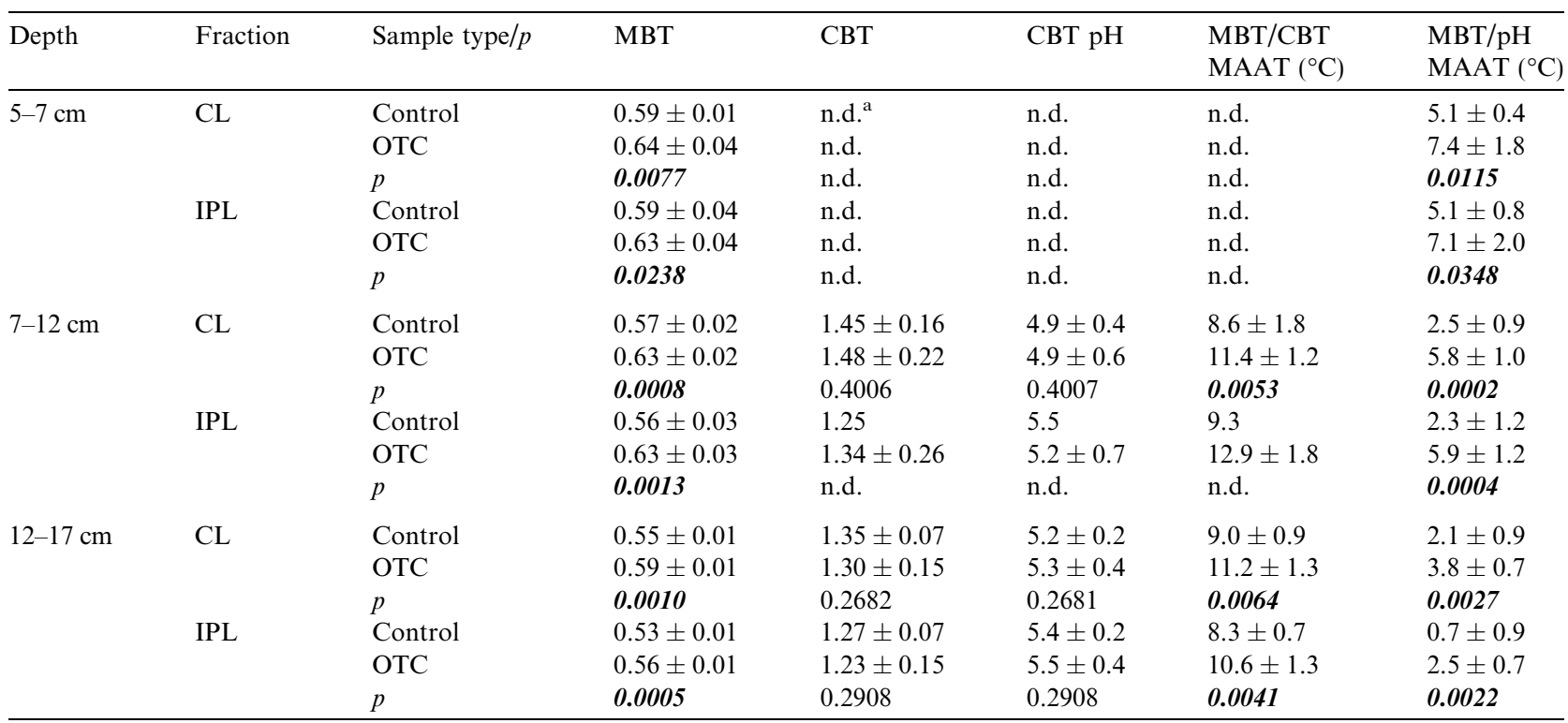

\footnotetext{
${ }^{\text {a }}$ GDGTs IIb and/or IIIb were not detected in peat samples collected at 5-7 $\mathrm{cm}$ depth, preventing determination of the CBT index.
} 
Table 6

Means and standard errors of the relative abundances of GDGTs Ia, IIa and IIIa, proxy values (MBT and CBT) and estimated pH and mean annual air temperature (MAAT) values from MBT and CBT indices for samples collected in June 2010 at $12-17 \mathrm{~cm} \mathrm{depth} \mathrm{in} \mathrm{control/OTC}$ plots. Data derived from the CL and IPL fractions were statistically compared $(n=6)$. $p$-Values from $t$-test for each of the parameters are listed under the means; those which are significantly different at the 0.05 level are bold and italicized.

\begin{tabular}{|c|c|c|c|c|c|c|}
\hline \multirow[t]{2}{*}{ Sample type } & \multirow[t]{2}{*}{ Fraction $/ p$} & \multicolumn{3}{|c|}{ Relative abundance $(\%)$} & \multirow[t]{2}{*}{ MBT } & \multirow{2}{*}{$\begin{array}{l}\mathrm{MBT} / \mathrm{pH} \\
\operatorname{MAAT}\left({ }^{\circ} \mathrm{C}\right) \\
\end{array}$} \\
\hline & & Ia & IIa & IIIa & & \\
\hline Control & $\begin{array}{l}\text { CL } \\
\text { IPL } \\
p\end{array}$ & $\begin{array}{l}50.8 \pm 1.5 \\
48.2 \pm 2.5 \\
\mathbf{0 . 0 4 3 4}\end{array}$ & $\begin{array}{l}36.9 \pm 1.0 \\
40.0 \pm 1.6 \\
0.0029\end{array}$ & $\begin{array}{l}6.8 \pm 0.9 \\
4.9 \pm 0.8 \\
\mathbf{0 . 0 0 5 3}\end{array}$ & $\begin{array}{l}0.55 \pm 0.01 \\
0.53 \pm 0.01 \\
\mathbf{0 . 0 0 5 3}\end{array}$ & $\begin{array}{l}2.1 \pm 0.9 \\
0.7 \pm 0.9 \\
\mathbf{0 . 0 2 3 9}\end{array}$ \\
\hline OTC & $\begin{array}{l}\text { CL } \\
\text { IPL } \\
p\end{array}$ & $\begin{array}{l}53.8 \pm 3.1 \\
50.1 \pm 2.8 \\
\mathbf{0 . 0 2 5 3}\end{array}$ & $\begin{array}{l}35.0 \pm 1.8 \\
35.9 \pm 2.3 \\
0.2397\end{array}$ & $\begin{array}{l}5.3 \pm 0.5 \\
5.2 \pm 1.2 \\
0.4525\end{array}$ & $\begin{array}{l}0.59 \pm 0.01 \\
0.56 \pm 0.01 \\
\boldsymbol{0 . 0 0 3 4}\end{array}$ & $\begin{array}{l}3.8 \pm 0.7 \\
2.5 \pm 0.7 \\
0.0037\end{array}$ \\
\hline
\end{tabular}

collected in 2008 and 2010 respectively). Whatever the lipid fraction, MAAT values derived from 2008 samples (about $10-11{ }^{\circ} \mathrm{C}$; Table 3 ) overestimated air temperature. In the same way, MAAT estimates derived from control and OTC plots for samples collected in 2010 (about $9^{\circ} \mathrm{C}$ for control plots and $11^{\circ} \mathrm{C}$ for OTCs; Table 5) were higher than instrumentally recorded MAAT (about $7^{\circ} \mathrm{C}$; Table 1). It should be noted that the significant differences in MBT values between the control and OTC plots observed in 2010 were also reflected in the MBT/CBT-derived temperatures (Table 5). Thus, MAAT estimates derived from CLs were in average $2.8^{\circ} \mathrm{C}$ higher in the OTCs than in the control plots at $7-12 \mathrm{~cm}$ depth and $2.2^{\circ} \mathrm{C}$ higher at $12-17 \mathrm{~cm}$ depth (Table 5).

Since CBT values could not be calculated for some samples, especially those collected at 5-7 cm depth in 2010, MAAT was also estimated from MBT and pH using Eq. 5 (Supplementary Tables 3 and 4). A similar trend was obtained using Eq. 5 instead of Eq. 4, i.e. whatever the lipid fraction, $\mathrm{MBT} / \mathrm{pH}$-derived temperatures for samples collected in 2010 were significantly higher (ca. $2-3{ }^{\circ} \mathrm{C}$ ) in the OTCs than in the control plots at all depths (Table 5). As actual $\mathrm{pH}$ are lower than the CBT-derived values, MBT$\mathrm{pH}$ derived temperatures are logically lower than MBT/ CBT estimates (Tables 3 and 5). MBT/pH-derived temperatures were consistent with observed MAAT at 5-7 cm depth for samples collected in 2010, but were lower than measured MAAT at 7-12 cm and 12-17 cm depth for samples collected in both 2008 (Table 3) and 2010 (Table 5).

There was no significant difference in $\mathrm{MBT} / \mathrm{pH}$-derived MAAT estimates between CL and IPL fractions for samples collected in 2010 at 5-7 and 7-12 cm depth $(p>0.05$; data not shown). In contrast, at $12-17 \mathrm{~cm}$ depth, MAAT values derived from CLs were significantly higher than those derived from IPLs for both OTC and control plots (Table 6). As for samples collected in 2008, MAAT values derived from CLs were only observed to be higher than those derived from IPLs at $7-12 \mathrm{~cm}$ depth and for OTC plots $\left(2.9^{\circ} \mathrm{C}\right.$ for CLs and $1.7^{\circ} \mathrm{C}$ for IPLs; $\left.p=0.044\right)$.

\section{DISCUSSION}

\subsection{Effects of OTCs on air and soil temperature}

Over the whole 2008-2010 period, mean air temperature tended to be higher in the OTCs than in the control plots, as a result of the significant increase (ca. $2{ }^{\circ} \mathrm{C}$; Table 1 ) in maximal air temperature in the OTCs. The effects of the OTC treatment were especially marked on spring and summer air temperature: between March and August, maximal air temperature significantly increased by ca. $3{ }^{\circ} \mathrm{C}$ in the OTC vs. control plots (Table 1). In addition, in summer, the OTC treatment induced a significant increase in mean air temperature (ca. $1^{\circ} \mathrm{C}$ ). Therefore, our results clearly indicate that the OTCs increased the air temperature. This is further supported by several other studies in peatlands, which similarly observed an increase in air temperature under the effect of the OTCs (e.g. Marion et al., 1997; Dorrepaal et al., 2004; Dabros and Fyles, 2010).

The OTCs also caused significant changes in daily soil thermal amplitude, especially in summer (Table 1): during this season, soil temperature reached higher and lower extremes at the bog site, whereas both maximal and minimum soil temperatures were lower in the OTCs than in the controls at the fen site. This was reflected in mean summer soil temperature, which was slightly higher in the OTCs than in the control plots at the bog site and significantly lower at the fen site. Maximal soil temperature varied in a similar way in spring and summer at both fen and bog sites. The variations of soil temperature between control and OTC plots could be interpreted as a consequence of increased evapotranspiration in OTCs, at least during spring and summer. Indeed, as recently explained by Dabros and Fyles (2010), higher air temperatures can induce higher evapotranspiration, resulting in lower soil moisture. Higher evapotranspiration may also lead to lower soil temperature by heat loss towards atmosphere and reduction of soil thermal conductivity (Delarue et al., 2011; Jassey et al., 2011): as soil moisture decreases and the air content in soil increases, the resistance to the transfer of heat increases, since heat diffuses faster in water than in air (Rosenberg et al., 1983; Hollister, 1998).

Concomitant and continuous measurements of air and soil moisture would be necessary to (i) fully understand the phenomenons of heat exchange and evapotranspiration between air and peat (Aerts et al., 2006; Delarue et al., 2011) and (ii) to explain the complex effects of the OTC treatment on environmental parameters (temperature, humidity) in heterogeneous systems such as the fen and bog sites investigated in this study. Even though such measurements have not been performed in Frasne peatland, we can assume that the increase in air temperature induced by 
the OTCs resulted in higher evapotranspiration in OTC than in control plots, especially at the fen site. Indeed, Jassey et al. (2011) determined the water content of Sphagnum in each plot from June to November 2009 and observed a significant decrease of Sphagnum moisture content in August and September in OTC plots of both bog and fen sites. This decrease was particularly high at the fen site (ca. 75$85 \%$ Sphagnum water content in control plots vs. $55-65 \%$ in OTC plots at $0-3 \mathrm{~cm}$ depth) and lower at the bog site (ca. 80-90\% Sphagnum water content in control plots vs. $75 \%$ in OTC plots at $0-3 \mathrm{~cm}$ depth). In addition, Delarue et al. (2011) measured the ratio of dry to wet matter in peat samples at $0-10 \mathrm{~cm}$ depth collected from each plot on June 2009. This ratio was higher for OTCs than for control plots at the fen site, whereas no specific effect of the OTCs was observed at the bog site. Last, peat humidity was measured continuously in 4 plots (one control and one OTC plot at both the bog and fen sites) with soil moisture sensors (Decagon, USA) from June to November 2010. Peat was observed to be slightly drier in OTC than in control plots (less than a $10 \%$ difference with control plots; Buttler et al., unpublished data). Taken together, these results indicate that the OTC treatment likely induced a decrease in peat moisture content and thus an increase in evapotranspiration, leading to drier and cooler soil conditions in the OTC plots, especially in the fen site. This could in turn explain the marginal effect of OTCs on mean soil temperature. This hypothesis is supported by the recent work of Dabros et al. (2010), who observed that the OTC treatment applied to a transitional boreal-mixed wood forest in northwestern Quebec led to higher air temperatures and at the same time to lower soil temperatures, as a result of increased evapotranspiration. This corresponds to the paradox of "colder soils in a warmer world", previously expressed by Groffman et al. (2001).

\subsection{Effects of OTC treatment on the abundance and distribution of branched GDGTs}

\subsubsection{Effects of OTC treatment on branched GDGT abundance}

At the beginning of the experiment (April 2008), the concentration of branched GDGTs was not significantly different in the OTC and control plots and was observed to increase with depth, from ca. 4-6 $\mu \mathrm{g} \mathrm{g}^{-1}$ dry wt. peat at $5-7 \mathrm{~cm}$ to almost $15-17 \mu \mathrm{g} \mathrm{g}^{-1}$ at $12-17 \mathrm{~cm}$ depth for CLs (Fig. 6a and Table 2). The analysis of the peat samples collected in 2010 revealed that the abundance of branched GDGTs was not affected by the OTC treatment, whatever the site (fen or bog; Fig. 7a and Table 4). In both control and OTC plots, the concentration of branched GDGT CLs increased similarly with depth, from ca. $1 \mu \mathrm{g} \mathrm{g}^{-1}$ dry wt. peat at $5-7 \mathrm{~cm}$ to almost $10 \mu \mathrm{g} \mathrm{g}^{-1}$ at $12-17 \mathrm{~cm}$ depth (Table 4). These concentrations are comparable to those observed for peat samples collected between 10 and $15 \mathrm{~cm}$ depth at the same experimental site on June 2008 (ca. 5$6 \mu \mathrm{g} \mathrm{g}^{-1}$ dry wt. peat; Huguet et al., 2010b) and slightly lower than those obtained for samples collected in 2008 (Table 2). Overall, the results obtained in the Frasne peatland are consistent with those of Weijers et al. (2006): these authors observed that branched GDGTs were present at very low concentration (less than $0.2 \mu \mathrm{g} \mathrm{g}^{-1}$ dry wt. peat) or were not detectable in the upper $10 \mathrm{~cm}$ of two peat cores collected in England, and were slightly more abundant (3$5 \mu \mathrm{g} \mathrm{g}^{-1}$ dry wt. peat) between 10 and $28 \mathrm{~cm}$ depth. Similarly, the concentration of branched GDGTs was observed to be ca. $20 \mu \mathrm{g} \mathrm{g}^{-1}$ in the first $10 \mathrm{~cm}$ of a Swiss peat bog (Etang de la Gruère; Weijers et al., 2011b). It should be noted that the present analysis of branched GDGTs is focussed on the upper part (i.e. the acrotelm) of the Frasne peatland, which was very likely the most impacted zone by the OTC treatment, but which is not the most favourable environment for the growth of branched GDGT-producing bacteria. Indeed, previous studies (e.g. Weijers et al., 2006, 2011b; Huguet et al., 2010b) revealed that branched GDGTs were much more abundant in the deeper anaerobic part (i.e. the catotelm) than in the surficial aerobic layer of peat bogs, leading to the hypothesis that branched GDGTproducing bacteria were anaerobic microorganisms (Weijers et al., 2006).

\subsubsection{Effects of the OTC treatment on branched GDGT distribution}

Branched GDGT distribution was affected by the OTC treatment, as reflected by the MBT values of peat samples collected in 2010, which were significantly higher in the OTCs than in the control plots at all depths, whatever the lipid fraction considered (Table 5 and Fig. 8a). In contrast, similar values of MBT were observed in control and OTC plots in April 2008 (Table 3 and Fig. 6b), confirming the effect of the OTC treatment on branched GDGT distribution after ca. 2 years of experiment. As discussed above, warming in OTC plots resulted in higher air temperature but should also have affected top-soil humidity. As a result, the increase in MBT observed in 2010 in the OTC plots could be related to changes in air temperature and/or in peat moisture content due to the OTC treatment.

Several recent studies suggest that humidity might have an effect on branched GDGT distribution. Indeed, we previously observed that the MBT was lower in the deeper, permanently water-saturated part of the Frasne peatland than in the upper and drier layer, where water table fluctuates (Huguet et al., 2010b). Additionally, the analysis of branched GDGTs in a peat core obtained from a raised bog in the Swiss Jura Moutains revealed lower MBT (and CBT) values in the deeper part dominated by Carex-derived peat than in the upper one dominated by Sphagnum and Eriophorum, supposed to be a drier type of peat (Weijers et al., 2011b). Last, Loomis et al. (2011) recently compared branched GDGT distributions in lacustrine sediments and catchment soils within a $3600 \mathrm{~m}$ altitudinal transect in Western Uganda. Significant differences in branched GDGT distributions between dry, well-drained soils and lake sediments were observed up to $3000 \mathrm{~m}$ asl, which may be due to the fact that in lakes branched GDGTs are produced in situ by different bacteria than in soils. In contrast, at higher elevations, branched GDGT distributions were similar in lacustrine sediments and soils, observed to be continuously water-saturated. Taken together, all these data support the idea that, besides temperature and $\mathrm{pH}$ (Weijers et al., 
2007a), soil humidity may play a role in the distribution pattern of branched GDGTs in peat and soils.

In the present study, it cannot be excluded that variations in peat moisture content induced by the OTC treatment at the surface of the peat might have had an influence on membrane lipid distribution of branched GDGT-producing bacteria. Indeed, as discussed in Section 4.1, peat moisture content in the OTC plots of the fen and bog sites might have been affected differently by the OTC treatment, with drier conditions at the surface of the fen site than at the one of the bog site (Delarue et al., 2011; Jassey et al., 2011). This might in turn explain the higher values of MBT index in the OTC plots of the fen site than in those of the bog site at 5-7 cm depth (Fig. 8a). In contrast, at $7-12 \mathrm{~cm}$ and $12-17 \mathrm{~cm}$ depth, MBT values in the OTC plots of the fen and bog sites were comparable, maybe because peat moisture content was much less impacted by the OTC treatment and that, at these depths, differences in peat moisture content between the fen and bog sites might not have been sufficient to induce significant variations in MBT values. This hypothesis is supported by the fact that the MBT values in the control plots of the fen and bog sites did not differ significantly (Fig. 8a) and that only small differences in peat moisture content (measured with soil moisture sensors at $7 \mathrm{~cm}$ depth between June and November 2010) were noted between the fen and bog control sites (less than 10\%; Buttler et al., unpublished data). Therefore, only large changes in peat moisture content (e.g. more than $20 \%$ or $30 \%$ ) could have an impact on the distribution of branched GDGTs.

In any case, differences in peat moisture content between the fen and bog sites did not induce significant variations in MBT values, except in the OTC plots at 5-7 cm depth. This suggests that air temperature warming was the main factor responsible for the changes in MBT values in the OTC plots. This is also supported by the fact that MBT values were similar in the control and OTC plots of the fen and bog sites in 2008, i.e. at the beginning of the warming experiment (Fig. 6b). Furthermore, based on the analysis of more than 130 superficial soil samples collected worldwide, Weijers et al. (2007a) showed that the MBT was related to MAAT and to a much lesser extent to soil $\mathrm{pH}$, with higher MBT values observed in warmer, more acidic soils. The causal relation between $\mathrm{pH}$ and temperature was confirmed by subsequent studies (e.g. Peterse et al., 2009a; Peterse et al., 2010). Since $\mathrm{pH}$ values were comparable in control and OTC plots (Supplementary Table 4 for samples collected in 2010) and air temperature was higher in OTCs, the results obtained in our study (higher MBT values in OTC plots 2 years after the beginning of the experiment) are compatible with the empirical relationship between MBT, MAAT and $\mathrm{pH}$ established by Weijers et al. (2007a) and suggest that the changes in MBT values induced by the OTC treatment were clearly related to changes in air temperature.

Branched GDGT-derived temperatures for samples collected in 2010 were higher in the OTCs than in the control plots of both bog and fen sites (Table 5). This is surprising, as the distribution of branched GDGT-producing bacteria can be assumed to be more strongly correlated with soil than with air temperature, since growth of branched GDGT-producing bacteria occur in soil. Mean and maximum soil temperatures were observed to be lower in the OTCs than in the control plots of the fen sites over the whole period from 2008 to 2010, and especially in the summer season (Table 1). Consequently, branched GDGT-derived temperature estimates would have been expected to follow the same trend. In contrast, the higher temperature estimates obtained in the OTC than in the control plots of the fen site suggest that at the peat surface, branched GDGT-producing bacteria were affected by variations in air, rather than soil temperature. Branched GDGTs were suggested to be produced by anaerobic bacteria, which, in the upper, aerobic part of peat bogs probably thrive in anoxic microsites in peat pores (Weijers et al., 2006). In near surface peat, temperature in the pores may be assumed to follow the temperature of the air above the vegetation carpet, likely explaining the relationship between branched GDGT distribution and air temperature.

\subsection{Reconstruction of peat $\mathrm{pH}$ and air temperature}

\subsubsection{Peat $p H$}

Peat $\mathrm{pH}$ was similar in control and OTC plots and the beginning of the experiment (Table 3 and Supplementary Table 3) and was not affected by the 2 years of OTC treatment, as shown by actual $\mathrm{pH}$ values (and also CBT-estimated $\mathrm{pH}$ ) which did not differ significantly between the OTC and control plots (Table 5 and Supplementary Table 4). Nevertheless, whatever the lipid fraction, CBT-estimated $\mathrm{pH}$ was systematically higher than actual $\mathrm{pH}$ values (Supplementary Tables 3 and 4). For most of the samples, the difference between measured and estimated $\mathrm{pH}$ was between 1.0 and 2.0 units, i.e. higher than the standard error of the CBT-pH calibration (0.8 units) established in soils by Weijers et al. (2007a). We observed a similar deviation between actual and estimated $\mathrm{pH}$ for peat samples collected in the acrotelm and catotelm parts of the Frasne peatland (Huguet et al., 2010b). Very recently, in the top part of the peat bog "Etang de la Gruère" located in Switzerland, CBT-pH estimates were also observed to be higher than actual $\mathrm{pH}$ values, with a difference of ca. 0.6 units (Weijers et al., 2011b). This suggests that, in peatlands, there may be a bias towards higher values for branched GDGT-derived $\mathrm{pH}$ estimates. This bias might come from the fact that the initial CBT-pH calibration set (Weijers et al., 2007a) does not contain any peat soil and could therefore indicate the need of a separate calibration taking into account the specificity of peat environments, particularly Shagnum peatlands characterized by very low $\mathrm{pH}$. As previously explained (Huguet et al., 2010b), the uncertainty in CBT-pH estimates might also be due (i) to the remaining scatter in the CBT-pH relationship (Weijers et al., 2007a) and (ii) to the low abundance of GDGTs IIb and IIIb used in the calculation of the CBT index.

\subsubsection{Air temperature}

Whatever the lipid fraction, MBT/CBT-derived MAAT estimates were higher than instrumentally recorded MAAT, with a difference between the two of (i) ca. $3{ }^{\circ} \mathrm{C}$ for control 
plots and ca. $2^{\circ} \mathrm{C}$ for OTC plots in 2008 (Table 3 to compare to Table 1) and (ii) ca. $2^{\circ} \mathrm{C}$ for control plots and ca. $3{ }^{\circ} \mathrm{C}$ for OTC plots in 2010 (Table 5 to compare to Table 1 ). Mean annual soil temperature at $7 \mathrm{~cm}$ depth was comparable to MAAT in control plots, and was only slightly lower than MAAT in control plots (Table 1). Consequently, MBT/CBT-derived temperatures in both 2008 and 2010 were also slightly higher $\left(\mathrm{ca} .2-3{ }^{\circ} \mathrm{C}\right.$ ) than mean annual soil temperature in both control and OTC plots. Our results support the recent observation of Weijers et al. (2011b), who noted that the deviation of branched GDGT-derived MAAT estimates towards higher temperatures appeared in several peat bogs for which branched GDGTs were analysed but that in most cases this deviation was in the standard error $\left( \pm 5^{\circ} \mathrm{C}\right)$ of the MBT-CBT-MAAT calibration (Eq. 3). As previously suggested (e.g. Sinninghe Damsté et al., 2008; Huguet et al., 2010b), using a specific calibration for peat soils rather than the global soil calibration could improve the accuracy of MAAT and also $\mathrm{pH}$ (see discussion above) reconstruction. It should be noted that in contrast with peat soils, MBT-CBT derived MAAT estimates were observed to be lower than instrumentally recorded temperatures in lacustrine environments (e.g. Tierney and Russell, 2009; Tierney et al., 2010; Pearson et al., 2011) likely due to the additional in situ production of branched GDGTs in lakes.

MAAT was also estimated from MBT and peat $\mathrm{pH}$ (Eq. 5). As previously observed in peat (Huguet et al., 2010b) and podzolic soils (Huguet et al., 2010a), MBT/pH-derived MAAT estimates were much lower than MBT/CBT-derived MAAT estimates. This discrepancy could be due to the low abundance of cyclopentyl-containing GDGTs Ib and IIb in peat samples, which may increase the analytical error in the CBT and the uncertainty in the determination of MAAT using the MBT and CBT (Eq. 3) and/or to the lower scattering of the data obtained via the MBT, $\mathrm{pH}$ and MAAT relationship $\left(R^{2} 0.82\right.$; Eq. 5$)$ than via the MBT, CBT and MAAT relationship ( $R^{2} 0.77$; Eq.3) (Weijers et al., 2007a).

Even though the difference between $\mathrm{MBT} / \mathrm{pH}$ - and MBT/CBT-derived MAAT values is appreciable, similar trends were obtained using Eqs. 3 and 5. Indeed, reconstructed temperatures were not significantly different in the OTC and control plots in 2008 (Table 3), except at 5$7 \mathrm{~cm}$ depth for the CL fraction. In contrast, MAAT estimates were significantly higher in the OTC than in the control plots in 2010, whatever the depth and the lipid fraction (Table 5). This is consistent with the observed effect of the OTCs on air temperature after 26 months of treatment.

Interestingly, the increase in actual maximum (daytime) air temperature induced by the OTCs in spring and summer (between 3 and $4{ }^{\circ} \mathrm{C}$; Table 1) was comparable to the difference in reconstructed temperatures between control and OTC plots (between ca. 2 and $3{ }^{\circ} \mathrm{C}$; Table 5). In addition, the effect of the OTCs was especially marked in spring and summer, with a significant increase in maximum air temperature during the two seasons and also in average air temperature during the summer (Table 1), whereas no significant effect of the OTCs was observed on the annual air temperature. Taken together, these results suggest that (i) the greatest impact of the OTC treatment on both air temperature and branched GDGT distribution likely occurred in spring and summer and that (ii) branched GDGT-producing bacteria could be more active in spring and summer than in winter, when many peatlands, such as the one investigated in this study, are snow-covered. If this was the case, the MAAT signal "recorded" by branched GDGT-producing bacteria would reflect seasonal rather than annual temperature. Indeed, MBT/CBT-derived temperatures were mainly comprised between 9 and $11^{\circ} \mathrm{C}$ (Tables 3 and 5 for samples collected in 2008 and 2010 respectively) and might be more consistent with spring and summer temperature (average air temperature between March and August 2008-2010: $10.5^{\circ} \mathrm{C}$ for the control plots and ca. $11^{\circ} \mathrm{C}$ in the OTC plots) than with annual temperature (ca. $7^{\circ} \mathrm{C}$; Table 1 ).

Several recent works also support the idea of a potential bias of branched GDGT temperature estimates toward seasonal temperatures, especially summer ones. For example, Rueda et al. (2009) compared instrumental temperature data with branched GDGT-derived MAAT estimates for a sediment core from the Skagerrak, off Norway, and found that MAAT values derived from the MBT and CBT were in closer agreement with summer than with annual air temperatures. It should nevertheless be noted that these data might be influenced by in situ production of branched GDGTs in the water column and/or marine sediments. Similarly, samples collected in deeper horizons of the Frasne peatland (up to ca. $50 \mathrm{~cm}$ depth) gave lower GDGT-derived MAAT estimates than those from surface horizons, consistent with the lower temperatures recorded in deep than in surficial horizons during the spring and summer seasons (Huguet et al., 2010b). Last, Weijers et al. (2011b) used branched GDGTs for the reconstruction of past temperatures in a peat bog from Switzerland and observed that, in the top part of the bog, estimated temperature $\left(\mathrm{ca} .13^{\circ} \mathrm{C}\right)$ was clearly higher than recorded annual soil $\left(8^{\circ} \mathrm{C}\right)$ and air $\left(5.5^{\circ} \mathrm{C}\right)$ temperatures. At shallowest depth, GDGT-derived MAAT estimates seem more consistent with pore water temperatures measured during the warmest months of the year, which range between ca. 11 and $16^{\circ} \mathrm{C}$ (Weijers et al., 2011b).

It has to be mentioned that the hypothesis of the higher activity of branched GDGT-producing bacteria in spring and summer was considered as unlikely by Weijers et al. (2011b), based on two main arguments. First, Harrysson Drotz et al. (2010) recently reported that both catabolic and anabolic processes can proceed in frozen boreal forest soil, including lipid biosynthesis. Second, branched GDGTs were analysed in 1-year time series of several mid-latitude soils and no seasonal trends in the concentrations and distributions of these molecules were observed (Weijers et al., 2011a). Despite these studies, the possibility of a lessened activity of branched GDGT-producing bacteria in winter cannot be excluded. Indeed, the view of Harrysson Drotz et al. (2010) that microbial synthesis and growth may continue when soil is frozen is not exclusive of a decrease of microbial activity at low temperatures. Thus, Blume et al. (2002) determined microbial biomass, community structure and metabolic activity in two mid-latitude soils (Indiana, 
United States) collected in both February and July. They showed that, while the size of the microbial biomass was not significantly affected by the seasonal variation, season did affect microbial community structure and activity, with a significant increase in microbial activity in summer compared to winter (up to $83 \%$ increase in soil surface; Blume et al., 2002). Therefore, even though all microorganisms or groups of microorganisms may not be similarly affected by changes in temperature, increased activity of branched GDGT-producing bacteria may clearly occur under warmer conditions during summer. It should also be noted that Sphagnum-dominated peatlands are specific ecosystems, characterized by low acidity ( $\mathrm{pH} 3.5-5.0)$, high organic matter content and low concentration of nutrients (Dedysh et al., 2006). These features make peat soils distinct from organo-mineral ones. Therefore, the activity of branched GDGT-producing bacteria might vary seasonally in peatlands, but not necessarily in organo-mineral soils (Weijers et al., 2011a). It cannot be totally excluded that the ecology of branched GDGT-producing bacteria - and even the group(s) of microorganisms producing branched GDGTs - might differ between peatlands and organo-mineral soils, leading to contrasted microbial activities in these two types of environments. The latter assertion is speculative since, to date, branched GDGT-producing bacteria have never been isolated and identified, even though Acidobacteria were suggested as potential source microorganisms for branched GDGTs (Weijers et al., 2009; Sinninghe Damsté et al., 2011).

In any case, the higher activity of branched GDGT-producing bacteria in spring and summer may only partly account for the warm bias in MBT/CBT-derived MAAT estimates observed in this study and in some other peatlands. Part of this bias may be inherent to the calibration of the MBT/CBT proxies and to the remaining scatter in the CBT-pH (Eq. 4) and MBT-pH-MAAT (Eq. 5) relationships. As previously suggested (Peterse et al., 2009a; Huguet et al., 2010b), this scatter can be explained by the fact that other environmental factors than temperature and $\mathrm{pH}$, such as peat moisture, oxygen content or nutrient amount may have an impact on the distribution of branched GDGTs in peat soils.

\subsection{Concentrations and distributions of branched GDGT core and intact polar lipids}

CL and IPL branched GDGTs were both investigated, because the two lipid pools might provide different environmental information: IPLs, which are assumed to be derived from living microorganisms, might better reflect the extant peat bacterial population than CLs, presumed to be of fossil origin. It should be noted that IPL branched GDGTs were not analysed directly: they were separated from CLs, submitted to acid hydrolysis and then quantified as CLs. The OTC treatment had no apparent effect on the production of branched GDGTs, as shown by the similar concentrations of IPL-derived GDGTs in OTC and control plots in 2008 (Table 2) and 2010 (Table 4). The proportion of IPL-derived GDGTs with respect to the total pool (i.e. CLs + IPLs) of branched GDGTs was comprised between
$15 \%$ and $30 \%$. This is consistent with values reported in previous works: for example, IPL-derived GDGTs comprised between $9 \%$ and $32 \%$ (on average $15 \%$ ) and between $9 \%$ and $19 \%$ of the total branched GDGT pool in the top $50 \mathrm{~cm}$ of the Saxnäs Mosse (South Sweden; Peterse et al., 2011b) and the upper $10 \mathrm{~cm}$ of Scottish soils (Peterse et al., 2010) respectively. This indicates that branched GDGTs in peat and soil are predominantly of fossil origin, as previously suggested (e.g. Weijers et al., 2009; Peterse et al., 2010; Huguet et al., 2010b).

Remarkably, the analysis of the MBT and CBT after 26 months of OTC treatment revealed no significant differences in branched GDGT distribution between the CL and IPL pools at 5-7 cm and 7-12 cm depth (Table 5) and at $12-17 \mathrm{~cm}$ depth, the MBT was only slightly higher in the $\mathrm{CL}$ than in the IPL-derived fraction. This was reflected in the branched GDGT-derived MAAT estimates, with similar values for the CL and IPL-derived fractions, except at $12-17 \mathrm{~cm}$ depth, where IPL-derived MAAT estimates were lower than CL-derived ones (Fig. 9 and Table 6). In any case, whatever the depth, both CL- and IPL-derived MAAT estimates were higher in the OTCs than in the control plots (Fig. 9). Taken together, these results indicate that branched GDGT-producing bacteria may rapidly adjust their membrane lipid composition to new environmental (at least temperature) conditions and suggest a very fast turnover of the fossil pool of branched GDGTs at the peat surface, i.e. less than the $\sim 2$ year duration of the experiment. This is in apparent contradiction with the work of Weijers et al. (2010), who estimated the turnover time of branched GDGTs to about 20 years, on the basis of the carbon isotopic composition of the branched alkanes released from branched GDGTs for two arable soils. Similarly, Peterse et al. (2010) analysed CL- and IPL-derived branched GDGTs in long term ( $>45$ years) soil $\mathrm{pH}$ manipulation plots and observed no significant differences in CBT-derived $\mathrm{pH}$ estimates between CL and IPL fractions, indicating a turnover time of branched GDGT CLs lower than 45 years. Even though these two studies seem to suggest that branched GDGTs turn over on timescales of decades, the latter one does not exclude a more rapid turnover time (a few years) for branched GDGTs in soils. In addition, the turnover time of branched GDGTs has only been estimated in two soils (Weijers et al., 2010) and has never been determined in peatlands, where branched GDGTs might turn over faster (especially in the acrotelm) than in organo-mineral soils. In the upper, aerobic part of peat bogs, organic matter is decomposed at a relatively rapid rate (Jørgensen, 2009) and up to $90 \%$ of OM produced by photosynthesis would be degraded by microorganisms (Clymo, 1984). Branched GDGTs might therefore be rapidly degraded (within a few years, as observed in this study) under the oxic conditions of the acrotelm. More generally, we speculate that the turnover time of branched GDGTs might vary depending on soil characteristics and conditions. Nevertheless, this hypothesis remains to be demonstrated by determining the turnover of these compounds in a wide range of contrasting soils, including peat, and at different depths. It should especially be noted that the turnover of branched GDGTs might differ between the acrotelm and the catot- 


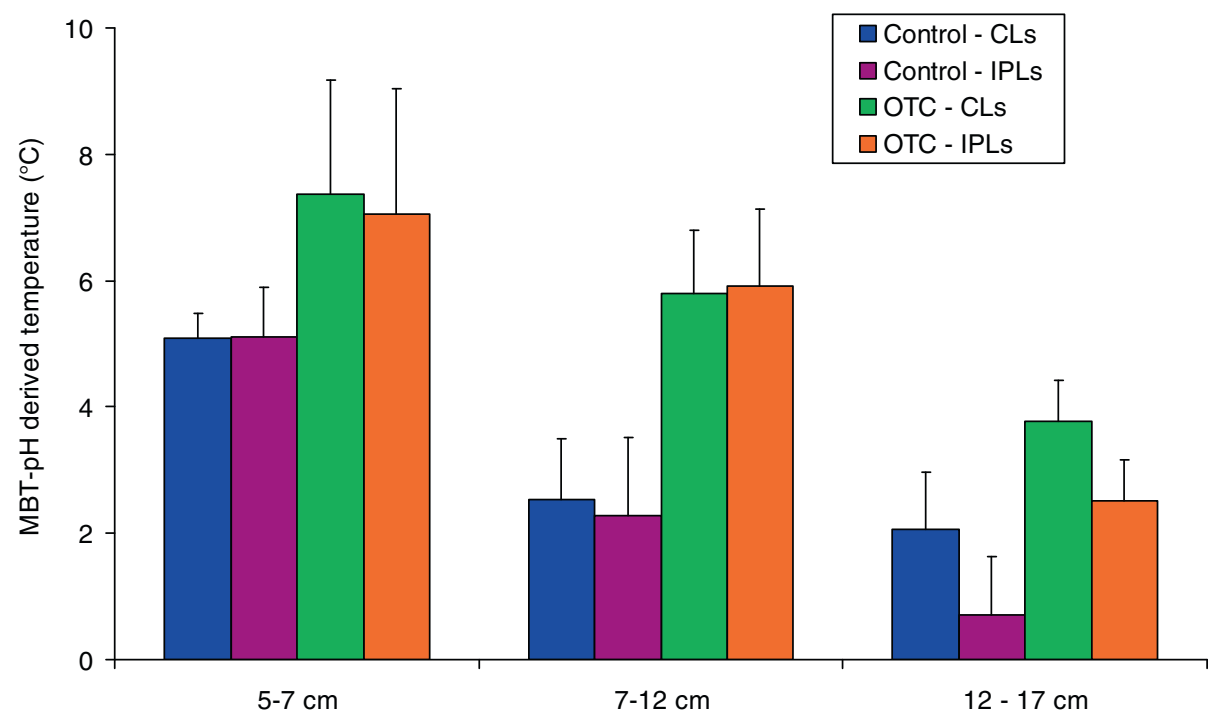

Fig. 9. Mean values and standard errors of MBT/pH-derived temperatures for OTC and control plots in June $2010(n=6)$.

Table 7

Means and standard errors of the relative abundances of GDGTs Ia, IIa and IIIa and of the MBT index for samples from the Frasne peatland incubated under controlled conditions at $12{ }^{\circ} \mathrm{C}$ and $15^{\circ} \mathrm{C}$ during 3 months. Data obtained at $12{ }^{\circ} \mathrm{C}$ and $15{ }^{\circ} \mathrm{C}$ were statistically compared $(n=3)$. $p$-Values from $t$-test for each of the parameters are listed under the means.

\begin{tabular}{llllll}
\hline Fraction & Temperature $/ p$ & \multicolumn{2}{l}{ Relative abundance $(\%)$} & IIIa \\
\cline { 3 - 5 } & & Ia & IIa & $6.7 \pm 0.6$ & $0.55 \pm 0.02$ \\
\hline $\mathrm{CL}$ & $12^{\circ} \mathrm{C}$ & $50.7 \pm 2.5$ & $36.4 \pm 0.7$ & $7.4 \pm 1.3$ & $0.54 \pm 0.02$ \\
& $15^{\circ} \mathrm{C}$ & $48.1 \pm 1.5$ & $37.2 \pm 1.6$ & 0.2082 & 0.4631 \\
& $p$ & 0.0948 & 0.2153 & $6.8 \pm 1.5$ & $0.53 \pm 0.01$ \\
IPL & $12{ }^{\circ} \mathrm{C}$ & $48.5 \pm 2.1$ & $38.2 \pm 1.3$ & $8.0 \pm 0.8$ & $0.54 \pm 0.02$ \\
& $15^{\circ} \mathrm{C}$ & $46.3 \pm 0.8$ & $35.6 \pm 3.5$ & 0.1456 & 0.2000 \\
\hline
\end{tabular}

elm, where anoxic conditions prevail and where branched GDGT-producing bacteria are more abundant (e.g. Weijers et al., 2006; Huguet et al., 2010b). The large pool of branched GDGTs present in the catotelm was not investigated in this study.

Very recently, columns of living Sphagnum and peat (height $13 \mathrm{~cm}$, diameter $25 \mathrm{~cm}$ ) collected in the Frasne peatland were incubated under controlled conditions at two different temperatures: 12 and $15^{\circ} \mathrm{C}$. The analysis of branched GDGT IPLs and CLs after 3 months of incubation revealed no significant differences in the relative abundances of the most abundant GDGTs (Ia, IIa and IIIa) and in the MBT index at 12 and $15^{\circ} \mathrm{C}$, whatever the lipid pool (Table 7; Huguet et al., unpublished results). This suggests that the turnover time of branched GDGT CLs and IPLs is longer than the 2 month duration of the incubation, but is likely lower than 2 years, as indicated by the results of the in situ experiment by OTC treatment.

IPLs are assumed to degrade very fast to CLs when their source organisms dies (White et al., 1979; Harvey et al., 1986), implying that the turnover of branched GDGT IPLs is likely faster than the one of CLs. The degradation of branched GDGT IPLs in peat will notably depend on the type of polar head groups (hexose- and/or phosphatebased) in these lipids, since phospholipids were observed to degrade faster than glycolipids (Harvey et al., 1986). To date, only a few studies examined the nature of functional head groups of branched GDGTs. Very recently, Peterse et al. (2011b) found phospho-head groups for branched GDGTs in peat and soils, in addition to glycosidic-head groups previously reported in a German peat bog by Liu et al. (2010). Furthermore, base and acid hydrolysis of soil samples revealed that the majority of the branched GDGT IPL pool consisted of phospholipids (Weijers et al., 2011a). Branched GDGT IPLs with phospho-head groups, which are supposedly rapidly degraded, might also be more abundant than glycolipids in peat, which should lead to a relatively fast turnover of branched GDGT IPLs. Nevertheless, Weijers et al. (2011a) suggested a turnover rate of ca. 1 year for branched GDGT IPLs in soil, based on the fact that no seasonal trend was observed in the distribution of branched GDGT IPLs in several soils. This might result from (i) a slow degradation rate of branched GDGT IPLs and/or (ii) long regeneration times 
of branched GDGT-producing bacteria (Weijers et al., 2011a). The turnover rate of branched GDGT IPLs could also be slower than expected in peat, which is supported by the fact that branched GDGT-producing bacteria did not adjust to changes in temperature after a 2-month incubation of peat (Table 7; Huguet et al., unpublished results). Overall, it might be assumed that branched GDGT IPLs turn over on timescales of a few months (less than 2 years and more than 3 months) in the upper part of peat bogs based on the results of the OTC treatment and of the 3month peat incubation.

As discussed above, it cannot be excluded that in the peatland investigated, branched GDGT-producing bacteria might be more active during spring and summer than during the rest of the year and therefore that MAAT estimates might be more consistent with seasonal (i.e. spring and summer) rather than annual temperature. If this was the case, an assumed turnover time of ca. 1 year for branched GDGT IPLs combined with a higher activity of branched GDGT-producing bacteria in spring and summer would imply that more than $50 \%$ of the IPL pool could be refreshed during the spring and summer months (i.e. Mars to August) and therefore that seasonal changes in temperature could be detected in the distribution of branched GDGT IPLs. Similarly, a large part of the CL pool (more than $25 \%$ based on an assumed turnover time of ca. 2 years and a higher activity of branched GDGT-producing bacteria in summer and spring than in autumn and winter) would be refreshed in spring and summer and could make apparent a warm bias in temperature estimates derived from branched GDGT CLs. In order to fully investigate the hypothesis of seasonal changes in the activity of branched GDGT-producing bacteria in peat, the concentrations and distributions of branched GDGTs in both CL and IPL pools should be monitored over a year.

\section{CONCLUSIONS}

Peatlands are predicted to be greatly affected by future global warming. In the present study, a moderate temperature rise was simulated in a temperate peatland (Frasne, France) using a warming system consisting of in situ open mini-greenhouses (OTCs). Air temperature was significantly impacted by the OTCs, with an increase of maximal (daytime) temperature of ca. $2^{\circ} \mathrm{C}$ over the whole 2008-2010 period and of ca. $3{ }^{\circ} \mathrm{C}$ in spring and summer. The effect of the OTCs was especially apparent in summer, with an increase of average air temperature of ca. $1{ }^{\circ} \mathrm{C}$. The OTC treatment also affected peat moisture content, with higher air temperatures likely leading to higher evapotranspiration and drier soil conditions.

Branched GDGT distribution did not significantly differ between the control and OTC plots at the beginning of the climate warming experiment. In contrast, after only 26 months, branched GDGT distribution was significantly affected by the OTC treatment, with higher MBT values in the OTC than in the control plots, supporting the empirical relationship between MBT and MAAT established from a large range of soils (Weijers et al., 2007a).
Branched GDGT-derived temperatures were also systematically higher in the OTC than in the control plots, consistent with the observed effect of the OTC treatment on air temperature. Interestingly, the difference in branched GDGT-derived temperatures between control and OTC plots (between ca. 2 and $3{ }^{\circ} \mathrm{C}$ ) was in the same range as the increase in maximum temperature induced by the OTCs in spring and summer (between ca. 3 and $4{ }^{\circ} \mathrm{C}$ ). This suggests that branched GDGT-producing bacteria might be more active in spring and summer than in winter, when peat is snow-covered. This might also account, at least partly, for the deviation of branched GDGT-derived MAAT estimates towards higher temperatures observed in this study and some other peat bogs. The analysis of branched GDGTs in several other peatlands is needed to confirm this hypothesis.

Core and intact polar lipid pools were both investigated. The relative and absolute abundances of branched GDGT CLs and IPLs were not modified by the OTC treatment. In all plots, branched GDGTs were shown to be mainly present as "fossil" CLs in Frasne peatland. The analysis of the MBT and CBT indices revealed no significant differences in branched GDGT distribution between the CLs and IPLs. Both lipid pools provided higher MBT and MAAT values for the OTC than the control plots after 2 years of OTC treatment. This suggests that the fossil pool of branched GDGTs has a very fast turnover (less than the 2 year duration of the experiment) at the peat surface and that branched GDGT distribution may rapidly reflect changes in environmental conditions (at least air temperature) occurring in peat environments. The results presented in this study must be extrapolated with caution due to the short duration of the climate treatment and to the fact that they are derived from a temperate peatland. Branched GDGT-producing bacteria might respond differently to climate forcing in peat environments located at higher latitudes (e.g. Artic and Antarctica). Long-term studies of several contrasted peatlands along latitudinal gradient are necessary to comprehensively evaluate the effect of climate change on branched GDGT-producing bacteria.

\section{ACKNOWLEDGMENTS}

This paper is a contribution of the PEATWARM project (Effect of moderate warming on the functioning of Sphagnum peatlands and their functions as a carbon sink) financially supported by the French National Agency (ANR-07-VUL-10). We thank AndréJean Francez (ECOBIO, France) for the laboratory incubations of peat cores collected in the Frasne peatland. We also thank Marie-Laure Toussaint (Chrono-Environnement, France) for the collection of temperature data. We are also grateful to three anonymous reviewers for constructive comments.

\section{APPENDIX A. SUPPLEMENTARY DATA}

Supplementary data associated with this article can be found, in the online version, at http://dx.doi.org/10.1016/ j.gca.2012.11.037. 


\section{REFERENCES}

Aerts R., Cornelissen J. H. C. and Dorrepaal E. (2006) Plant performance in a warmer world: general responses of plants from cold, northern biomes and the importance of winter and spring events. Plant Ecol. 182, 65-77.

Aerts R., Cornelissen J. H. C., Dorrepaal E., van Logtestijn R. S. P. and Callaghan T. V. (2004) Effects of experimentally imposed climate scenarios on flowering phenology and flower production of subartic bog species. Glob. Change Biol. 10, 1599-1609.

Ballantyne A. P., Greenwood D. R., Sinninghe Damsté J. S., Csank A. Z., Eberle J. J. and Rybczynski N. (2010) Significantly warmer Artic surface temperatures during the Pliocene indicated by multiple independent proxies. Geology 38, 603606.

Bechtel A., Smittenberg R. H., Bernasconi S. M. and Schubert C. J. (2010) Distribution of branched and isoprenoid tetraehter lipids in a oligotrophic and a eutrophic Swiss lake: insights into sources and GDGT-based proxies. Org. Geochem. 41, 822-832.

Blume E., Bischoff M., Reichert J. M., Moorman T., Konopka A. and Turco R. F. (2002) Surface and subsurface microbial biomass, community structure and metabolic activity as a function of soil depth and season. Appl. Soil Ecol. 20, 171-181.

Clymo R. S. (1984) The limits to peat bog growth. Philos. Trans. $R$. Soc. B 303, 605-654.

Dabros A. and Fyles J. W. (2010) Effects of open-top chambers and substrate type on biogeochemical processes at disturbed boreal forest sites in northwestern Quebec. Plant Soil 327, 465-479.

Dabros A., Fyles J. W. and Strachan J. B. (2010) Effects on opentop chambers on physical properties of air and soil at postdisturbance sites in northwestern Quebec. Plant Soil 333, 203218.

Dedysh S. N., Pankratov T. A., Belova S. E., Kulichevskaya I. S. and Liesack W. (2006) Phylogenetic analysis and in situ identification of bacteria community composition in an acidic sphagnum peat bog. Appl. Environ. Microb. 72, 2110-2117.

Delarue F., Laggoun-Défarge F., Buttler A., Gogo S., Jassey V. E. J. and Disnar J.-R. (2011) Effect of short-term experimental warming on water-extractable organic matter in an ombrotrophic Sphagnum peatland (Le Forbonnet, France). Org. Geochem. 42, 1016-1024.

Donders T. H., Weijers J. W. H., Munsterman D. K., Hoeve M. L. K. V., Buckles L. K., Pancost R. D., Schouten S., Sinninghe Damsté J. S. and Brinkhuis H. (2009) Strong climate coupling of terrestrial and marine environments in the Miocene of northwest Europe. Earth Planet. Sci. Lett. 281, 215-225.

Dorrepaal E., Aerts R., Cornelissen J. H. C., Callaghan T. V. and van Logtestijn R. S. P. (2004) Summer warming and increased winter snow cover affect Sphagnum fuscum growth, structure and production in a sub-arctic bog. Glob. Change Biol. 10, 93104.

Gorham E. (1991) Northern peatlands: role in carbon cycle and probable responses to climate warming. Ecol. Appl. 1, 182-195.

Groffman P. M., Driscoll C. T., Fahey T. J., Hardy J. P., Fitzhugh R. D. and Tierney G. L. (2001) Colder soils in a warmer world: a snow manipulation study in a northern hardwood forest ecosystem. Biogeochemistry 56, 135-150.

Harrysson Drotz S., Sparrman T., Nilsson M. B., Schleucher J. and Öquist M. G. (2010) Both catabolic and anabolic heterotrophic microbial activity proceed in frozen soils. Proc. Natl. Acad. Sci. USA 107, 21046-21051.

Harvey H. R., Fallon R. D. and Patton J. S. (1986) The effect of organic matter and oxygen on the degradation of bacterial membrane lipids in marine sediments. Geochim. Cosmochim. Acta 50, 795-804.
Hollister R. D. (1998) Response of wet meadow tundra to interannual and manipulated temperature variation: implications for climate change research. MSc thesis, Michigan State University.

Hopmans E. C., Schouten S., Pancost R. D., van der Meer M. T. J. and Sinninghe Damsté J. S. (2000) Analysis of intact GDGT lipids in archaeal cell material and sediments by high performance liquid chromatography/atmospheric pressure chemical ionization mass spectrometry. Rapid Commun. Mass Spectrom. 14, 585-589.

Hopmans E. C., Weijers J. W. H., Schefuß E., Herfort L., Sinninghe Damsté J. S. and Schouten S. (2004) A novel proxy for terrestrial organic matter in sediments based on branched and isoprenoid tetraether lipids. Earth Planet. Sci. Lett. 224, 107-116.

Huguet A., Fosse C., Metzger P., Fritsch E. and Derenne S. (2010a) Distribution of extractable glycerol dialkyl glycerol tetraethers in podzols. Org. Geochem. 41, 291-301.

Huguet A., Fosse C., Laggoun-Défarge F., Toussaint M.-L. and Derenne S. (2010b) Occurrence and distribution of glycerol dialkyl glycerol tetraethers in a French peat bog. Org. Geochem. 41, 559-572.

Jassey V. E. J., Chiapusio G., Gilbert D., Buttler A., Toussaint M.L. and Binet P. (2011) Experimental climate effect on seasonal variability of polyphenol/phenoloxidase interplay along a narrow fen-bog ecological gradient in Sphagnum fallax. Glob. Change Biol. 17, 2945-2957.

Jørgensen S. E. (2009) Ecosystem Ecology. Academic press.

Kim J.-H., Ludwig W., Schouten S., Kerhervé P., Herfort L., Bonnin J. and Sinninghe Damsté J. S. (2007) Impact of flood events on the transport of terrestrial organic matter to the ocean: a study of the Têt River (SW France) using the BIT index. Org. Geochem. 38, 1593-1606.

Kim J.-H., Talbot H. M., Zarzycka B., Bauersachs T. and Wagner T. (2011) Occurrence and abundance of soil-specific bacterial membrane lipid markers in the Têt watershed (southern France): soil-specific BHPs and branched GDGTs. Geochem. Geophys. Geosyst. 12, Q02008. http://dx.doi.org/10.1029/ 2010GC003364.

Laiho R. (2006) Decomposition in peatlands: reconciling seemingly contrasting results on the impacts of lowered water table level. Soil Biol. Biochem. 38, 2011-2024.

Lipp J. S. and Hinrichs K.-U. (2009) Structural diversity and fate of intact polar lipids in marine sediments. Geochim. Cosmochim. Acta 73, 6816-6833.

Liu X.-L., Leider A., Gillepsie A., Gröger J., Verstegh G. J. M. and Hinrichs K.-U. (2010) Identification of polar lipid precursors of the ubiquitous branched GDGT orphan lipids in a peat bog in Northern Germany. Org. Geochem. 41, 653-660.

Loomis S. E., Russell J. M. and Sinninghe Damsté J. S. (2011) Distributions of branched GDGTs in soils and lake sediments from western Uganda: implications for a lacustrine paleothermometer. Org. Geochem. 42, 739-751.

Marion G. M., Henry G. H. R., Freckman D. W., Johnstone J., Jones G., Jones M. H., Levesque E., Molau U., Molagaard P., Parsons A. N., Svoboda J. and Virgina R. A. (1997) Open-top designs for manipulating field temperature in high-latitude ecosystems. Glob. Change Biol. 3, 20-32.

Pearson E. J., Juggins S., Talbot H. M., Weckström J., Rosén P., Ryvesn D. B., Roberts S. J. and Schmidt R. (2011) A lacustrine GDGT-temperature calibration from the Scandinavian Arctic to Antarctic: Renewed potential for the application of GDGTpaleothermometry in lakes. Geochim. Cosmochim. Acta 75, 6225-6238.

Peterse F., Schouten S., van der Meer J., van deer Meer M. T. J. and Sinninghe Damsté J. S. (2009a) Distribution of branched 
tetraether lipids in geothermally heated soils: implications for the MBT/CBT temperature proxy. Org. Geochem. 40, 201-205.

Peterse F., van der Meer M. T. J., Schouten S., Jia G., Ossebaar J., Blokker J. and Sinninghe Damsté J. S. (2009b) Assessment of soil $n$-alkane $\delta \mathrm{D}$ and branched tetraether membrane lipid distributions as tools for paleoelevation reconstruction. Biogeosciences 6, 2799-2807.

Peterse F., Nicol G. W., Schouten S. and Sinninghe Damsté J. S. (2010) Influence of soil $\mathrm{pH}$ on the abundance and distribution of core and intact polar lipid-derived branched GDGTs in soil. Org. Geochem. 41, 1171-1175.

Peterse F., Prins M. A., Beets C. J., Troelstra S. R., Zheng H., Gu Z., Schouten S. and Sinninghe Damsté J. S. (2011a) Decoupled warming and monsoon precipitation in East Asia over the last deglaciation. Earth Planet. Sci. Lett. 301, 256-264.

Peterse F., Hopmans E. C., Schouten S., Mets A., Rijpstra I. C. and Sinninghe Damsté J. S. (2011b) Identification and distribution of intact polar branched tetraether lipids in peat and soil. Org. Geochem. 42, 1007-1015.

Rosenberg N. J., Blad B. L. and Verma S. B. (1983) Microclimate; the Biological Environment. Wiley, New York.

Rueda G., Rosell-Melé A., Escala M., Gyllencreutz R. and Backman J. (2009) Comparison of instrumental and GDGT based estimates of sea surface and air temperatures from the Skagerrak. Org. Geochem. 40, 287-291.

Sinninghe Damsté J. S., Hopmans E. C., Pancost R. D., Schouten S. and Geenevasen J. A. J. (2000) Newly discovered nonisoprenoid glycerol dialkyl glycerol tetraether lipids in sediments. Chem. Commun., 1683-1684.

Sinninghe Damsté J. S., Ossebaar J., Schouten S. and Verschuren D. (2008) Altitudinal shifts in the branched tetraether lipid distribution in soil from Mt. Kilimanjaro (Tanzania): implications for the MBT/CBT continental palaeothermometer. Org. Geochem. 39, 1072-1076.

Sinninghe Damsté J. S., Rijpstra W. I., Hopmans E. C., Weijers J. W. H., Foesel B. U., Overmann J. and Dedysh S. N. (2011) 13,16-Dimethyl octacosanedioic acid (iso-diabolic acid), a common membrane-spanning lipid of Acidobacteria subdivisions 1 and 3. Appl. Environ. Microb. 77, 4147-4154.

Svenson S. and Thompson D. H. (1998) Facile and efficient synthesis of bolaamphilic tetraether phosphocholines. J. Org. Chem. 21, 7180-7182.

Tierney J. E. and Russell J. M. (2009) Distributions of branched GDGTs in a tropical lake system: implications for lacustrine application of the MBT/CBT paleoproxy. Org. Geochem. 40, 1032-1036.
Tierney J. E., Russell J. M., Eggermont H., Hopmans E. C., Verschuren D. and Sinninghe Damsté J. S. (2010) Environmental controls on branched tetraether lipid distributions in tropical East African lake sediments. Geochim. Cosmochim. Acta 74, 4902-4918.

Weijers J. W. H., Schouten S., Hopmans E. C., Geenevasen J. A. J., David O. R. P., Coleman J. M., Pancost R. D. and Sinninghe Damsté J. S. (2006) Membrane lipids of mesophillic anaerobic bacteria thriving in peats have typical archaeal traits. Environ. Microbiol. 8, 648-657.

Weijers J. W. H., Schouten S., van den Donker J. C., Hopmans E. C. and Sinninghe Damsté J. S. (2007a) Environmental controls on bacterial tetraether membrane lipid distribution in soils. Geochim. Cosmochim. Acta 71, 703-713.

Weijers J. W. H., Schefuss E., Schouten S. and Sinninghe Damsté J. S. (2007b) Coupled thermal and hydrological evolution of tropical Africa over the last deglaciation. Science 315, 17011704.

Weijers J. W. H., Panoto E., van Bleijswijk J., Schouten S., Rijpstra W. I. C., Balk M., Stams A. J. M. and Sinninghe Damsté J. S. (2009) Constraints on the biological source(s) of the orphan branched tetraether lipids. Geomicrobiol. J. 26, 402-414.

Weijers J. W. H., Wiesenberg G. L. B., Bol R., Hopmans E. C. and Pancost R. D. (2010) Carbon isotopic composition of branched tetraether membrane lipids in soils suggest a rapid turnover and a heterotrophic lifestyle of their source organism(s). Biogeosciences 7, 2959-2973.

Weijers J. W. H., Bernhardt B., Peterse F., Werne J. P., Dungait A. J., Schouten S. and Sinninghe Damsté J. S. (2011a) Absence of seasonal patterns in MBT-CBT indices in mid-latitude soils. Geochim. Cosmochim. Acta 75, 3179-3190.

Weijers J. W. H., Steinmann P., Hopmans E. C., Schouten S. and Sinninghe Damsté J. S. (2011b) Bacterial tetraether membrane lipids in peat and coal: Testing the MBT-CBT temperature proxy for climate reconstruction. Org. Geochem. 42, 477-486.

White D. C., Davis W. M., Nickels J. S., King J. D. and Bobbie R. J. (1979) Determination of the sedimentary microbial biomass by extractable lipid phosphate. Oecologia 40, 51-62.

Zink K.-G., Vandergoes M. J., Mangelsdorf K., DieffenbacherKrall A. C. and Schwark L. (2010) Application of bacterial glycerol dialkyl glycerol tetraethers (GDGTs) to develop modern and past temperature estimates from New Zealand lakes. Org. Geochem. 41, 1060-1066.

Associate editor: Josef P. Werne 